\title{
Juvenile Sucker Cohort Tracking Data Summary and Assessment of Monitoring Program, 2015
}

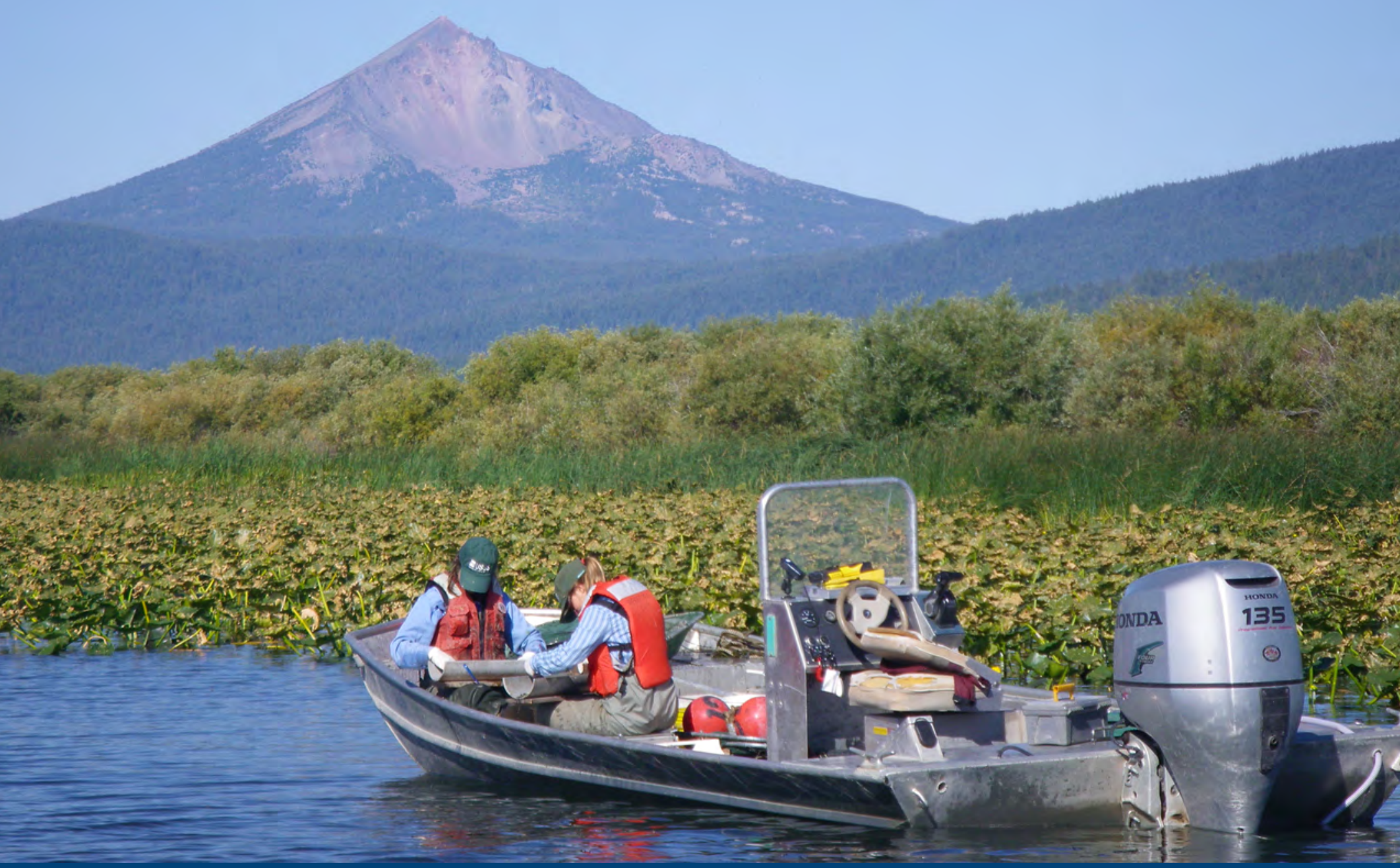

Open-File Report 2016-1164

U.S. Department of the Interior U.S. Geological Survey 
Cover: Photograph showing researchers looking for suckers in trap net catches from Upper Klamath Lake, Oregon. Photograph by Todd Perry, U.S. Geological Survey, August 21, 2014. 


\section{Juvenile Sucker Cohort Tracking Data Summary and Assessment of Monitoring Program, 2015}

By Summer M. Burdick, Carl O. Ostberg, Mark E. Hereford, and Marshal S. Hoy

Open-File Report 2016-1164

U.S. Department of the Interior

U.S. Geological Survey 


\section{U.S. Department of the Interior \\ SALLY JEWELL, Secretary}

\section{U.S. Geological Survey \\ Suzette M. Kimball, Director}

U.S. Geological Survey, Reston, Virginia: 2016

For more information on the USGS—-the Federal source for science about the Earth,

its natural and living resources, natural hazards, and the environment-visit

http://www.usgs.gov/ or call 1-888-ASK-USGS (1-888-275-8747).

For an overview of USGS information products, including maps, imagery, and publications, visit http://store.usgs.gov.

Any use of trade, firm, or product names is for descriptive purposes only and does not imply endorsement by the U.S. Government.

Although this information product, for the most part, is in the public domain, it also may contain copyrighted materials as noted in the text. Permission to reproduce copyrighted items must be secured from the copyright owner.

Suggested citation:

Burdick, S.M., Ostberg, C.O., Hereford, M.E., and Hoy, M.S., 2016, Juvenile sucker cohort tracking data summary and assessment of monitoring program, 2015: U.S. Geological Survey Open-File Report 2016-1164, 30 p., http://dx.doi.org/10.3133/ofr20161164.

ISSN 2331-1258 (online) 


\section{Contents}

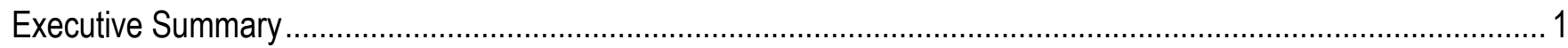

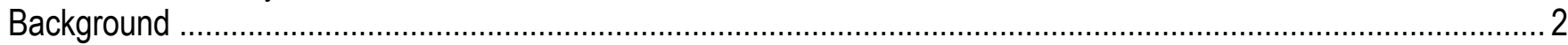

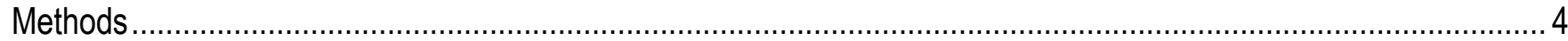

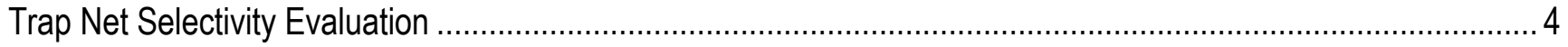

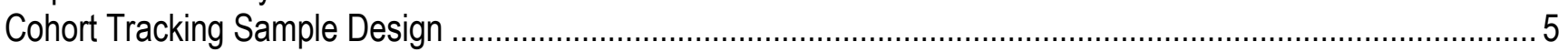

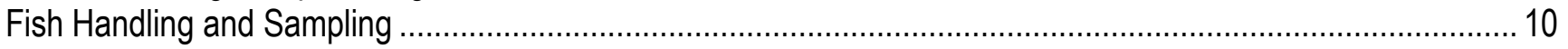

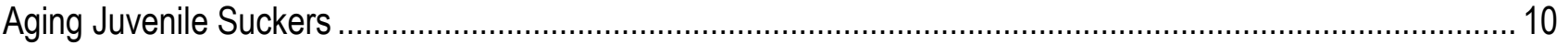

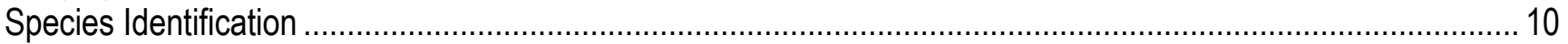

Indices of Juvenile Sucker Production and Survival .............................................................................. 11

Apparent Growth and Summary of Afflictions ...................................................................................... 12

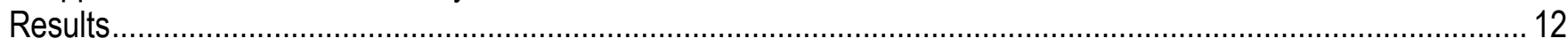

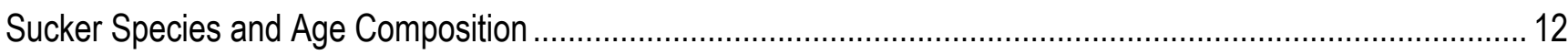

Capture Efficiency and Size Selectivity .............................................................................................. 13

Evaluation of Assumptions for Survival Analyses.................................................................................. 15

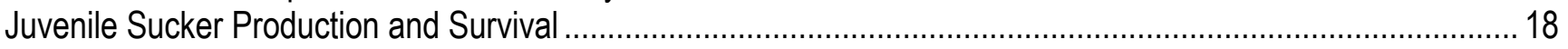

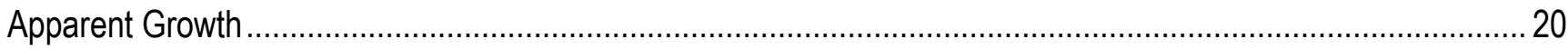

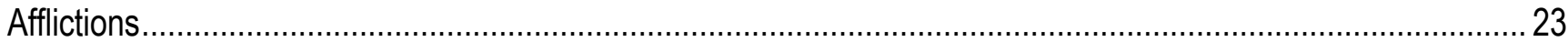

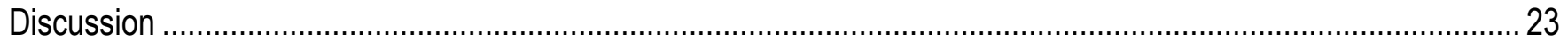

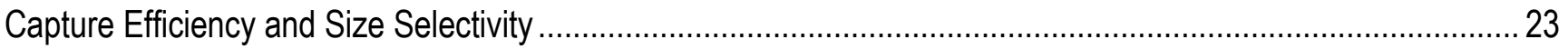

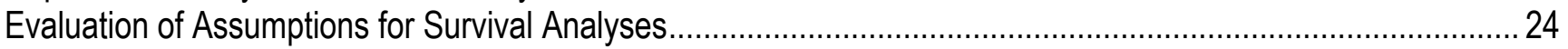

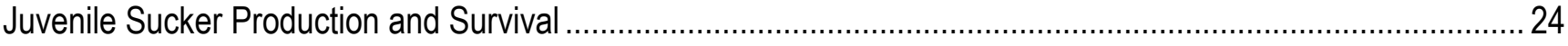

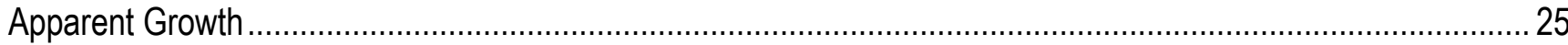

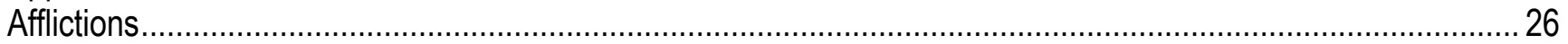

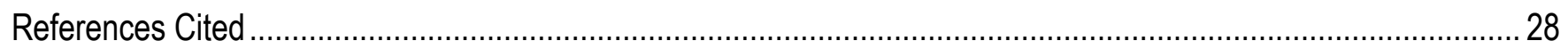

\section{Figures}

Figure 1. Locations of sample sites used to capture juvenile suckers in Upper Klamath Lake, Klamath County,

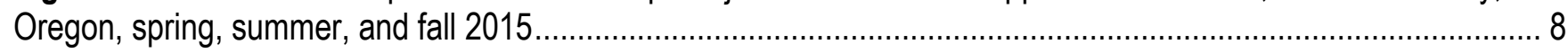

Figure 2. Locations of sample sites used to capture juvenile suckers in Clear Lake Reservoir, Modoc County, California, spring, summer, and fall 2015

Figure 3. Number of annuli on fin ray sections and corresponding standard length (millimeter) for 38 suckers collected from Barclay Springs in Hagelstein Park, Oregon.....

Figure 4. Proportional catch by 20 millimeter standard length grouping of suckers in Barkley Springs in Hagelstein Park, Oregon.

Figure 5. Probability of species assignment based on STRUCTURE for age-0 juvenile suckers shown for nine sites sampled, Upper Klamath Lake, Oregon, 2015

Figure 6. Natural log of the catch per net of suckers by the number of annuli on fin rays (presumed age) for 3 year classes captured in Clear Lake Reservoir, California.

Figure 7. Standard length by day of the year for shortnose suckers and Lost River suckers with one annuli on fin rays (presumed age-0) captured in Upper Klamath Lake, Oregon, 2015.

Figure 8. Standard length and the number of annuli on fin ray sections from 172 suckers captured from Upper Klamath Lake, Oregon, 2015

Figure 9. Standard length and number of annuli on fin ray sections from all 24 suckers captured in trap nets from Clear Lake Reservoir, California, 2015 


\section{Tables}

Table 1. Number of nets fished for juvenile suckers by area and sampling period in Upper Klamath Lake, Oregon, 2015.

Table 2. Number of nets fished for juvenile suckers by area and sampling period in Clear Lake Reservoir, California, 2015

Table 3. Number of marked suckers available for capture and recaptured by sampling date from

Barkley Springs in Hagelstein Park, Oregon

Table 4. Number of trap nets and catch statistics by area sampled, Upper Klamath Lake, Oregon,

August 2015

Table 5. Proportion of catch (number of individual fish) by number of annuli on fin ray section (presumed age) of suckers captured in fixed and randomly selected sites during three sampling periods, Upper Klamath Lake, Oregon, 2015.

Table 6. Proportion of catch (number of individual fish) by species in fixed and randomly selected sampling sites during three sampling periods, Upper Klamath Lake, Oregon, 2015.

Table 7. Percentage of nets and mean catch to catch one or more age-0 sucker in Upper Klamath Lake, Oregon, August and September 2015

Table 8. Index of instantaneous rate of apparent natural mortality $(M)$ and annual apparent survival (S) for three cohorts of suckers captured in Clear Lake Reservoir, California

\section{Conversion Factors}

U.S. Customary Units to International System of Units

\begin{tabular}{lcc}
\hline & Bultiply & To obtain \\
\hline & Length & \\
\hline inch (in) & 2.54 & centimeter $(\mathrm{cm})$ \\
\hline & Flow rate & \\
\hline cubic foot per second $\left(\mathrm{ft}^{3} / \mathrm{s}\right)$ & 0.02832 & cubic meter per second $\left(\mathrm{m}^{3} / \mathrm{s}\right)$ \\
\hline
\end{tabular}

International System of Units to Inch/Pound

\begin{tabular}{|c|c|c|}
\hline Multiply & By & To obtain \\
\hline \multicolumn{3}{|c|}{ Length } \\
\hline centimeter $(\mathrm{cm})$ & 0.3937 & inch (in.) \\
\hline millimeter (mm) & 0.03937 & inch (in.) \\
\hline meter $(\mathrm{m})$ & 3.281 & foot $(\mathrm{ft})$ \\
\hline kilometer $(\mathrm{km})$ & 0.6214 & mile (mi) \\
\hline \multicolumn{3}{|c|}{ Area } \\
\hline millimeter squared $\left(\mathrm{mm}^{2}\right)$ & 0.00155 & Inches squared $\left(\mathrm{in}^{2}\right)$ \\
\hline
\end{tabular}

Temperature in degrees Celsius $\left({ }^{\circ} \mathrm{C}\right)$ may be converted to degrees Fahrenheit $\left({ }^{\circ} \mathrm{F}\right)$ as:

$$
{ }^{\circ} \mathrm{F}=\left(1.8 \times{ }^{\circ} \mathrm{C}\right)+32 .
$$




\title{
Juvenile Sucker Cohort Tracking Data Summary and Assessment of Monitoring Program, 2015
}

\author{
By Summer M. Burdick, Carl O. Ostberg, Mark E. Hereford, and Marshal S. Hoy
}

\section{Executive Summary}

Populations of federally endangered Lost River (Deltistes luxatus) and shortnose suckers (Chasmistes brevirostris) in Upper Klamath Lake, Oregon, are experiencing long-term declines in abundance. Upper Klamath Lake populations are decreasing because adult mortality, which is relatively low, is not being balanced by recruitment of young adult suckers into known adult spawning aggregations. Previous sampling for juvenile suckers indicated that most juvenile sucker mortality in Upper Klamath Lake likely occurs within the first year of life. The importance of juvenile sucker mortality to the dynamics of Clear Lake Reservoir populations is less clear, and factors other than juvenile mortality (such as access to spawning habitat) play a substantial role. For example, production of age- 0 juvenile suckers, as determined by fin ray annuli and fin development, has not been detected since 2013 in Clear Lake Reservoir, whereas it is detected annually in Upper Klamath Lake.

We initiated a long-term juvenile sucker monitoring program in 2015 designed to track cohorts through seasons and among years in both Upper Klamath Lake and Clear Lake Reservoir. Specifically, our goals are to track annual variability in age- 0 sucker production, juvenile sucker survival, growth, and condition. In this first year of the monitoring program, we assessed assumptions that sampled fish were representative of populations of suckers in each lake. The size, age, and species composition of suckers were similar between randomly determined sites and fixed sites in each lake. We captured a wide size and age range of suckers using similar gear, indicating our gear did not exclude older and larger fish. We identified improvements that could be made in the monitoring program including increasing the number of randomly determined sample sites in both lakes, evaluation of gear-size selectivity, and validation of aging methods for juvenile Lost River and shortnose suckers.

Differing age composition of juvenile suckers between lakes in our 2015 catches and as reported in previous studies indicate that juvenile suckers are produced in relatively larger numbers each year in Upper Klamath Lake than in Clear Lake Reservoir. Most (96.6 percent) of suckers captured in Upper Klamath Lake in 2015 were age-0, whereas age- 0 or age- 1 suckers were not captured in Clear Lake Reservoir. Despite ample effort, age- 0 suckers have not been captured in Clear Lake Reservoir since 2013. Estimated ages of suckers captured in 2015 in Clear Lake Reservoir ranged from 2 to 6 years. Low flow during spawning seasons in the only known spawning tributary to Clear Lake Reservoir (Willow Creek) appears to explain the lack of age-0 sucker production in recent years. 
Juvenile sucker mortality is relatively higher in Upper Klamath Lake than in Clear Lake Reservoir. We compared data collected in 2015 to previously published catch rates to produce an index of annual juvenile sucker survival for these species. We calculated indices of annual apparent survival of juvenile sucker ages 0-5 years old in Clear Lake Reservoir to be between $0.37( \pm 0.06$ standard error [SE]) and $0.44( \pm 0.08 \mathrm{SE})$. This is the first time indices of annual apparent survival for Lost River and shortnose suckers have been calculated. This estimate has the limitation of being non-species specific because not all individuals were identified to species in previous years, and suckers that were identified included both taxa. In contrast, catch rates decreased by 89 percent for juvenile Lost River suckers and decreased 50 percent for juvenile shortnose suckers in Upper Klamath Lake between August and September 2015. Very low catch rates of age-1 and older suckers in Upper Klamath Lake indicate that annual juvenile sucker survival rates are near zero.

Condition of suckers was assessed in 2015 based on age-0 sucker growth rates in Upper Klamath Lake and the prevalence of externally observable afflictions on suckers from both lakes. Age-0 Lost River suckers grew an average ( \pm standard deviation [SD]) of $0.72( \pm 0.01)$ millimeters $[\mathrm{mm}]$ standard length [SL] per day, and age-0 shortnose suckers grew an average of $0.57( \pm 0.04) \mathrm{mm}$ SL per day in 2015. This growth rate was similar to growth rates reported for these species in Upper Klamath Lake in previous years. Opercular deformities, skin hemorrhages, black-spot causing parasites, and Lernaea spp. parasitism were the most common afflictions observed on suckers. Observed afflictions were primarily on suckers from Upper Klamath Lake, with the exception of Lernaea spp., which occurred more frequently on suckers from Clear Lake Reservoir. Opercular deformities and black-spot causing parasites were each observed on 5 percent of age-0 suckers from Upper Klamath Lake. Petechial hemorrhaging of the skin was observed on 43 percent of age-0 Lost River suckers, 38 percent of age-0 suckers of undetermined taxa, and only 24 percent of age- 0 shortnose suckers from Upper Klamath Lake. Petechial hemorrhaging of the skin was only observed on a single shortnose sucker from Clear Lake Reservoir. Within Upper Klamath Lake, the prevalence of these hemorrhages was exactly twice as high as was reported in 2014.

\section{Background}

Lost River sucker (Deltistes luxatus) and shortnose sucker (Chasmistes brevirostris) are jointly listed as endangered under the Endangered Species Act (U.S. Fish and Wildlife Service, 1988). Two of the remaining spawning populations of both Lost River sucker and shortnose sucker exist in Upper Klamath Lake (Klamath County, Oregon) and Clear Lake Reservoir (Modoc County, California) (U.S. Fish and Wildlife Service, 2013). Both species are lake dwelling catostomids that make springtime migrations from about 4 to 7 years of age to lake shore or tributaries spawning areas (Hewitt and others, 2015). Upper Klamath Lake populations typically spawn from March to June, whereas Clear Lake Reservoir populations spawn from February to April (Hewitt and Hayes, 2013; Burdick, Hewitt, and others, 2015; Hewitt and others, 2015). Larvae of Upper Klamath Lake river spawning populations outmigrate at night in May and early June to in-lake rearing habitats within several days of emerging from gravel (Cooperman and Markle, 2003). Clear Lake sucker larvae out-migrate from Willow Creek in April and May (Sutphin and Tyler, 2016). Age-0 juvenile suckers of both taxa are widely distributed throughout Upper Klamath Lake in late-July and August and there is no evidence of directed migrations during this time period (Hendrixson, Burdick, Herring, and others, 2007; Burdick and others, 2009; Burdick and Hewitt, 2012). Age-1 and older juvenile suckers are also widely distributed throughout Clear Lake Reservoir, but little is known about the distribution of age-0 juvenile suckers in that system (Burdick and Rasmussen, 2013). 
The persistence of Upper Klamath Lake sucker populations is threatened by a prolonged lack of recruitment into adult spawning aggregations (National Research Council, 2004; U.S. Fish and Wildlife Service, 2013). Uncertainty exists regarding if Clear Lake Reservoir populations are similarly recruitment limited, because recruitment in Clear Lake Reservoir is intermittent but not infrequent (Hewitt and Hayes, 2013). In Upper Klamath Lake, decreasing catch rates of age- 0 juvenile suckers during August and September in most years and a lack of age-1 or older juvenile sucker catches indicate that the lack of recruitment is due to high mortality within the first year of life (Burdick and VanderKooi, 2010). In contrast, a more even age distribution of juvenile suckers has been documented in Clear Lake Reservoir, indicating that juvenile sucker survival may be greater than in Upper Klamath Lake (Burdick, Elliott, and others, 2015).

Over the last 2 decades, research and monitoring data have been collected on juvenile Lost River and shortnose suckers in Upper Klamath Lake. Juvenile suckers in Upper Klamath Lake were consistently monitored by Oregon State University (OSU) from 1997 to 2012. The U.S. Geological Survey (USGS) conducted various research projects from 2001 to 2010 and from 2012 to 2014 with the objectives of understanding habitat use and distribution of age- 0 and age- 1 juvenile suckers. OSU sampled with beach seines, cast nets, and trawls using a consistent study design among years but captured small numbers of suckers relative to USGS sampling with trap nets. Locations and sampling gears used were inconsistent across USGS research projects, making these data unsuitable for monitoring long-term trends. The OSU dataset indicates that the strongest year classes for both species within the last 17 years probably occurred in 1998, 1999, and 2011 (Simon and others, 2013). Relatively strong cohorts for both species also were documented by both OSU and USGS in 2006 (Burdick and others, 2008). Because the OSU and USGS sampling occurred primarily in the summer, overwinter and summer to fall survival could not be assessed with data collected in either sampling program.

Recovery of Lost River and shortnose sucker populations requires increasing the number of suckers surviving to maturity. Recovery actions 6.1 and 6.2 in U.S. Fish and Wildlife Service's recovery plan include assessment and monitoring of juvenile sucker populations in Upper Klamath Lake and Clear Lake Reservoir (U.S. Fish and Wildlife Service, 2013). A long-term monitoring program exists for adult suckers at spawning areas aimed at tracking recruitment into the spawning populations in Upper Klamath Lake and Clear Lake Reservoir (Hewitt and others, 2015). Nevertheless, this adult sucker monitoring program has not detected substantial recruitment into spawning populations, as would be expected 4-7 years after suckers hatch. For example, a relatively strong cohort of age-0 suckers was detected in Upper Klamath Lake by OSU and USGS programs in 2006; this cohort appeared not to survive to age 2 and has still not been detected in spawning populations.

An assumption of catch based indices of fish production, survival, and growth is that sampling provides an unbiased representation of populations. Biased samples can result from size or age selective gear or study designs that do not account for heterogeneous distributions by size or age of fish (Kraft and Johnson, 1992; Allen and Hightower, 2010). Assessment of size based gear selectivity that can occur with trap nets is an important consideration in a monitoring program (Hubert and others, 2012). Young-of-year juvenile suckers, as defined by age and morphological development, are found in all accessible habitats with water 0.5 to $4.0 \mathrm{~m}$ deep between the last week of July and the first week of September within Upper Klamath Lake (Burdick and Brown, 2010; Burdick and Hewitt, 2012). However, age-1 suckers are more likely to be found in shallow near-shore habitats in the spring and deep water in the summer (Bottcher and Burdick, 2010; Burdick and Hewitt, 2012). Spatial patterns among age classes of suckers have not been identified in Clear Lake Reservoir, which has more homogeneous habitat (Burdick and Rasmussen, 2012). 
Species composition is also an important consideration for a long-term juvenile sucker monitoring program. Clear Lake Reservoir suckers are distinct from Upper Klamath Lake suckers in species composition and morphological differences within species (Markle and others, 2005; Burdick and Rasmussen, 2012). Shortnose suckers, with a strong morphological likeness to Klamath largescale suckers (Catostomus snyderi), made up about 80 percent of juvenile suckers and Lost River suckers comprised the remaining juvenile suckers in Clear Lake Reservoir in a 2012 pilot study (Burdick and Rasmussen, 2013). In comparison, approximately equal numbers of juvenile Lost River and shortnose suckers are captured in Upper Klamath Lake (Bottcher and Burdick, 2010; Burdick and Hewitt, 2012). Larval and small juvenile $(<40 \mathrm{~mm} \mathrm{SL})$ shortnose suckers are slightly more likely to be found in nearshore habitats than Lost River suckers in Upper Klamath Lake (Burdick and Hewitt, 2012; Simon and others, 2013). However, there is no difference in the distribution of the two taxa of age-0 suckers larger than about $40 \mathrm{~mm}$ SL relative to distance from shore from mid-July to September (Hendrixson, Burdick, Herring, and others, 2007).

We initiated a new juvenile sucker monitoring program in 2015 with the intention of generating relative indices of juvenile Lost River and shortnose sucker production, growth, and survival in both Upper Klamath Lake and Clear Lake Reservoir. This monitoring program aims to track cohorts both within and among years. Data are anticipated to be useful for identification of environmental variables affecting annual production and survival of young suckers. The dataset also will be useful for understanding collective effects of recovery actions on production, survival, and growth of juvenile suckers. In this report, we summarize the first year of data collected and evaluate the required assumptions and study design for meeting the intended long-term goals of the monitoring program.

\section{Methods}

\section{Trap Net Selectivity Evaluation}

Trap nets are a type of passive gear that requires fish to swim into the nets and be retained in a series of fykes. Bias against capture of small fish can occur when fish cross sectional width is less than the mesh size (Kraft and Johnson, 1992). Bias against capture of larger fish is likely a function of behavior (Laarman and Ryckman, 1982). Bias also occurs because capture efficiency depends on the interception probability, which is a function of how much fish move and where gear is placed relative to their movement path (Clavero and others, 2006). Season, water temperature, and turbidity are the most influential factors affecting behavior and thus trap net efficiency on larger fish (Hubert and others, 2012). If behavior were to vary among fish of varying sizes or ages, it could cause a size selective pattern that would lead to biases in apparent survival indices.

We designed a study to examine capture efficiency and to evaluate our assumption of equal size selectivity of trap nets. This study was carried out in Barkley Springs at Hagelstein Park, which is a $1,328 \mathrm{~m}^{2}$ pond located off the eastern shore of Upper Klamath Lake (42 $23^{\circ} 01.04 \mathrm{~N}, 121^{\circ} 48^{\prime} 45.17$ $\mathrm{W})$. The outlet of the pond is a small stream less than $1 \mathrm{~m}$ wide and approximately $20 \mathrm{~cm}$ deep. We conducted our study during three time periods: May 19-22, July 27-31, and September 21-25. During each of these 1-week sampling periods, we installed a nylon net with 1/4-inch mesh that was reinforced with larger wire mesh at the outlet of the pond to temporarily block fish passage. The net was removed after each sampling period. During each sampling period, we fished five to seven trap nets overnight. Nets were identical to those fished in Upper Klamath Lake and Clear Lake Reservoir. We also electrofished the pond and the outlet channel on the first day of each 1-week sampling period. The outlet channel was fished with a Smith Root backpack electrofishing unit and two netters, whereas the pond was fished by mounting the same electrofishing unit on the bow of a drift boat. During drift boat fishing, two netters collected suckers. To reduce the possibility of trap avoidance, fin rays were 
collected for aging from only a subset of 38 (21 percent) suckers, which were all captured on the last day of each week-long Barclay Springs sampling event. A fin clip with a fin location unique to each sampling week was used to both mark suckers and collect a sample for genetic identification. Standard length was measured and recorded for each sucker. All suckers collected were released into the pond. Suckers recaptured within the week they were fin clipped were not given a new clip.

We calculated the number of marked individuals recaptured over 3 days in each of three time periods for a total of nine separate estimates of capture efficiency. From these data, we calculated a mean and standard deviation of the recapture rate of all marked individuals. To examine size selectivity, we compared the proportion of marked and recaptured individuals in $20 \mathrm{~mm}$ length classes (Hamley and Regier, 1973).

\section{Cohort Tracking Sample Design}

We sampled during three 3-week periods (seasons) in 2015. Sampling timing was based on previous data that indicated that age composition and catch rates may vary substantially among seasons. The duration of each seasonal sampling period was selected based on the presumption that 3 weeks was the shortest amount of time that we could sample at least 60 nets in each lake. Based on historical catch data, we predicted that 60 net sets was the fewest nets that would be likely to catch at least 30 age- 0 suckers in years with somewhat poor production. The first sampling season was the first three 5-day work weeks in June, supported by previous research that indicated that age-1 suckers are most likely to be captured at that time of year (Bottcher and Burdick, 2010). Our second sampling season was the first 3 full weeks in August, in which catches of age-0 suckers were historically greatest in Upper Klamath Lake (Bottcher and Burdick, 2010). Samples were collected during the last 2 weeks of September and extended into the earliest part of October, because that is a time period in which catches of age- 0 suckers have been typically low (Hendrixson, Burdick, Herring, and others, 2007; Hendrixson, Burdick, VanderKooi, and others, 2007).

We selected fixed 1-km long sample areas to represent the variety of shoreline habitats within each lake. Totals of 10 shoreline areas within Upper Klamath Lake and 10 areas within Clear Lake Reservoir were selected for sampling (tables 1 and 2; figs. 1 and 2). Due to periodic drying or shallow water conditions, the eastern lobe of Clear Lake Reservoir is inaccessible in some years and seasons. Therefore, effort was focused in the western lobe, and only one area in the eastern lobe of Clear Lake Reservoir was selected as a fixed sample site. Within fixed areas, nets were set at 5 sites in June and September in Upper Klamath Lake, 6 sites in June and September in Clear Lake Reservoir, and 10 sites in August. Three of 247 nets set in Upper Klamath Lake and 3 of 236 nets set in Clear Lake Reservoir failed and were removed from the dataset (tables 1 and 2). Previous sampling indicated that species and age composition throughout each lake would be accurately represented in the fixed sites selected (Burdick and Brown, 2010; Burdick and Rasmussen, 2013). To further assure that the age or species composition of samples was unbiased, we sampled 19 randomly selected sites in Clear Lake and 50 randomly selected sites in Upper Klamath Lake for comparison. The number of randomly determined sites fished each season varied due to number of staff available to conduct sampling. Randomly determined site locations were evenly allocated between near shore ( $<100 \mathrm{~m}$ from shore) and off shore ( $\geq 500 \mathrm{~m}$ from shore). 
Table 1. Number of nets fished for juvenile suckers by area and sampling period in Upper Klamath Lake, Oregon, 2015.

[Area locations are shown in figure 1. Seasons were designated based on timing of seasonal peaks in historical catches of age-1 suckers, age-0 suckers in summer and low catches of both age classes in the fall. Two nets at the Wood River Wetland and one at the Shoalwater Bay site failed to fish properly and were excluded from this table. Latitude/Longitude coordinates for the mid-point of each area based on North American Datum of 1983]

\begin{tabular}{|c|c|c|c|c|c|c|}
\hline \multirow{2}{*}{ Area } & \multirow{2}{*}{ Latitude } & \multirow{2}{*}{ Longitude } & \multirow{2}{*}{ Habitat description } & \multicolumn{3}{|c|}{ Number of nets fished } \\
\hline & & & & June 2-16 & August 4-20 & September $15-29$ \\
\hline Wood River Wetland & $42^{\circ} 34^{\prime} 18.84^{\prime \prime} \mathrm{N}$ & $121^{\circ} 56^{\prime} 27.44^{\prime \prime} \mathrm{W}$ & River mouth & 5 & 8 & 5 \\
\hline Fish Banks north & $42^{\circ} 28^{\prime} 53.18^{\prime \prime} \mathrm{N}$ & $122^{\circ} 3^{\prime} 22.89^{\prime \prime} \mathrm{W}$ & Submergent vegetation & 5 & 10 & 5 \\
\hline Fish Banks south & $42^{\circ} 26^{\prime} 25.19^{\prime \prime} \mathrm{N}$ & $122^{\circ} 3^{\prime} 20.45^{\prime \prime} \mathrm{W}$ & Submergent vegetation & 5 & 10 & 5 \\
\hline Pelican Bay & $42^{\circ} 27^{\prime} 48.44^{\prime \prime} \mathrm{N}$ & $122^{\circ} 4^{\prime} 37.62^{\prime \prime} \mathrm{W}$ & Submergent vegetation & 5 & 10 & 5 \\
\hline Tulana & $42^{\circ} 29^{\prime} 5.56^{\prime \prime} \mathrm{N}$ & $121^{\circ} 57^{\prime} 19.40^{\prime \prime} \mathrm{W}$ & Restored shallow (1-2 m) water lake & 5 & 10 & 5 \\
\hline Shoalwater Bay & $42^{\circ} 25^{\prime} 16.54^{\prime \prime} \mathrm{N}$ & $121^{\circ} 57^{\prime} 45.27^{\prime \prime} \mathrm{W}$ & Deep (4-5 m) water with rocky shoreline & 4 & 10 & 5 \\
\hline Haglestein (in lake) & $42^{\circ} 23^{\prime} 0.79^{\prime \prime} \mathrm{N}$ & $121^{\circ} 48^{\prime} 56.44^{\prime \prime} \mathrm{W}$ & Shallow water with rocky shoreline & 5 & 10 & 5 \\
\hline Howard Bay & $42^{\circ} 20^{\prime} 49.72^{\prime \prime} \mathrm{N}$ & $121^{\circ} 54^{\prime} 57.38^{\prime \prime} \mathrm{W}$ & Emergent vegetation & 5 & 10 & 5 \\
\hline Hanks Marsh & $42^{\circ} 18^{\prime} 17.85^{\prime \prime} \mathrm{N}$ & $121^{\circ} 50^{\prime} 13.72^{\prime \prime} \mathrm{W}$ & Emergent vegetation & 5 & 10 & 5 \\
\hline Moore Park & $42^{\circ} 14^{\prime} 6.57^{\prime \prime} \mathrm{N}$ & $121^{\circ} 48^{\prime} 46.31^{\prime \prime} \mathrm{W}$ & Open water & 5 & 10 & 5 \\
\hline Random & Various & Various & Various & 10 & 20 & 20 \\
\hline Total net sets & & & & 59 & 118 & 70 \\
\hline
\end{tabular}


Table 2. Number of nets fished for juvenile suckers by area and sampling period in Clear Lake Reservoir, California, 2015.

[Area locations are shown in figure 2. Seasons were designated based on timing of seasonal peaks in historic catches of age-1 suckers, age-0 suckers in summer, and low catches of both age classes in the fall in Upper Klamath Lake, Oregon. One net failed in September at the mouth of the straits and was not included in this table]

\begin{tabular}{|c|c|c|c|c|c|c|}
\hline \multirow[b]{2}{*}{ Area } & \multirow[b]{2}{*}{ Latitude } & \multirow[b]{2}{*}{ Longitude } & \multirow[b]{2}{*}{ Habitat description } & \multicolumn{3}{|c|}{ Number of nets fished } \\
\hline & & & & June 4-18 & August 6-21 & $\begin{array}{l}\text { September 15- } \\
\text { October } 1\end{array}$ \\
\hline $\begin{array}{l}\text { Dam to Willow Creek } \\
\text { mouth (Dam Channel) }\end{array}$ & $41^{\circ} 55^{\prime} 24.80^{\prime \prime} \mathrm{N}$ & $121^{\circ} 4^{\prime} 56.75^{\prime \prime} \mathrm{W}$ & Deep to shallow, dredged channel & 0 & 10 & 10 \\
\hline The Rocks & $41^{\circ} 53^{\prime} 25.75^{\prime \prime} \mathrm{N}$ & $121^{\circ} 10^{\prime} 26.15^{\prime \prime} \mathrm{W}$ & Rocky shoreline & 6 & 10 & 6 \\
\hline West Mouth of Straits & $41^{\circ} 52^{\prime} 58.76^{\prime \prime} \mathrm{N}$ & $121^{\circ} 9^{\prime} 35.24^{\prime \prime} \mathrm{W}$ & Shallow with clay substrate & 6 & 10 & 5 \\
\hline Section A & $41^{\circ} 53^{\prime} 31.72^{\prime \prime} \mathrm{N}$ & $121^{\circ} 13^{\prime} 21.14^{\prime \prime} \mathrm{W}$ & $\begin{array}{l}\text { Shallow with clay substrate and } \\
\text { gravel shoal }\end{array}$ & 6 & 10 & 6 \\
\hline East Shore & $41^{\circ} 52^{\prime} 11.56^{\prime \prime} \mathrm{N}$ & $121^{\circ} 9^{\prime} 10.31^{\prime \prime} \mathrm{W}$ & Rocky & 6 & 10 & 6 \\
\hline Vegetation Patch & $41^{\circ} 51^{\prime} 4.47^{\prime \prime} \mathrm{N}$ & $121^{\circ} 12^{\prime} 40.10^{\prime \prime} \mathrm{W}$ & Shallow with submergent vegetation & 6 & 10 & 6 \\
\hline South Rock Reef & $41^{\circ} 50^{\prime} 47.41^{\prime \prime} \mathrm{N}$ & $121^{\circ} 9^{\prime} 34.39^{\prime \prime} \mathrm{W}$ & Rocky with clay around rocks & 6 & 10 & 6 \\
\hline South Shore & $41^{\circ} 49^{\prime} 11.02^{\prime \prime} \mathrm{N}$ & $121^{\circ} 8^{\prime} 34.03^{\prime \prime} \mathrm{W}$ & Shallow with clay substrate & 6 & 10 & 6 \\
\hline Southwest Shore & $41^{\circ} 50^{\prime} 0.46^{\prime \prime} \mathrm{N}$ & $121^{\circ} 11^{\prime} 7.77^{\prime \prime} \mathrm{W}$ & Shallow with clay substrate & 6 & 10 & 6 \\
\hline Random West Lobe & Various & Various & Various & 6 & 10 & 3 \\
\hline
\end{tabular}




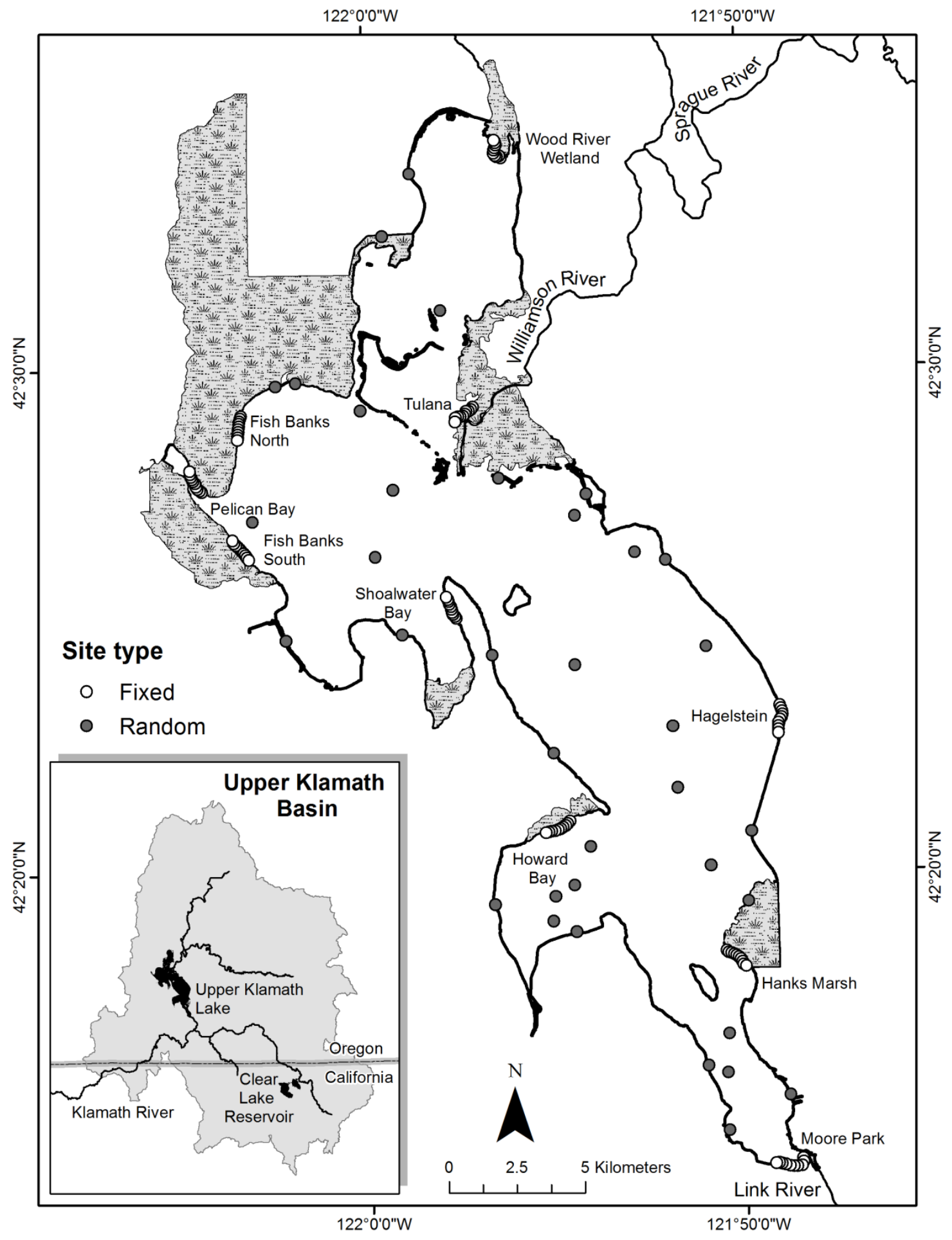

Figure 1. Locations of sample sites used to capture juvenile suckers in Upper Klamath Lake, Klamath County, Oregon, spring, summer, and fall 2015. 


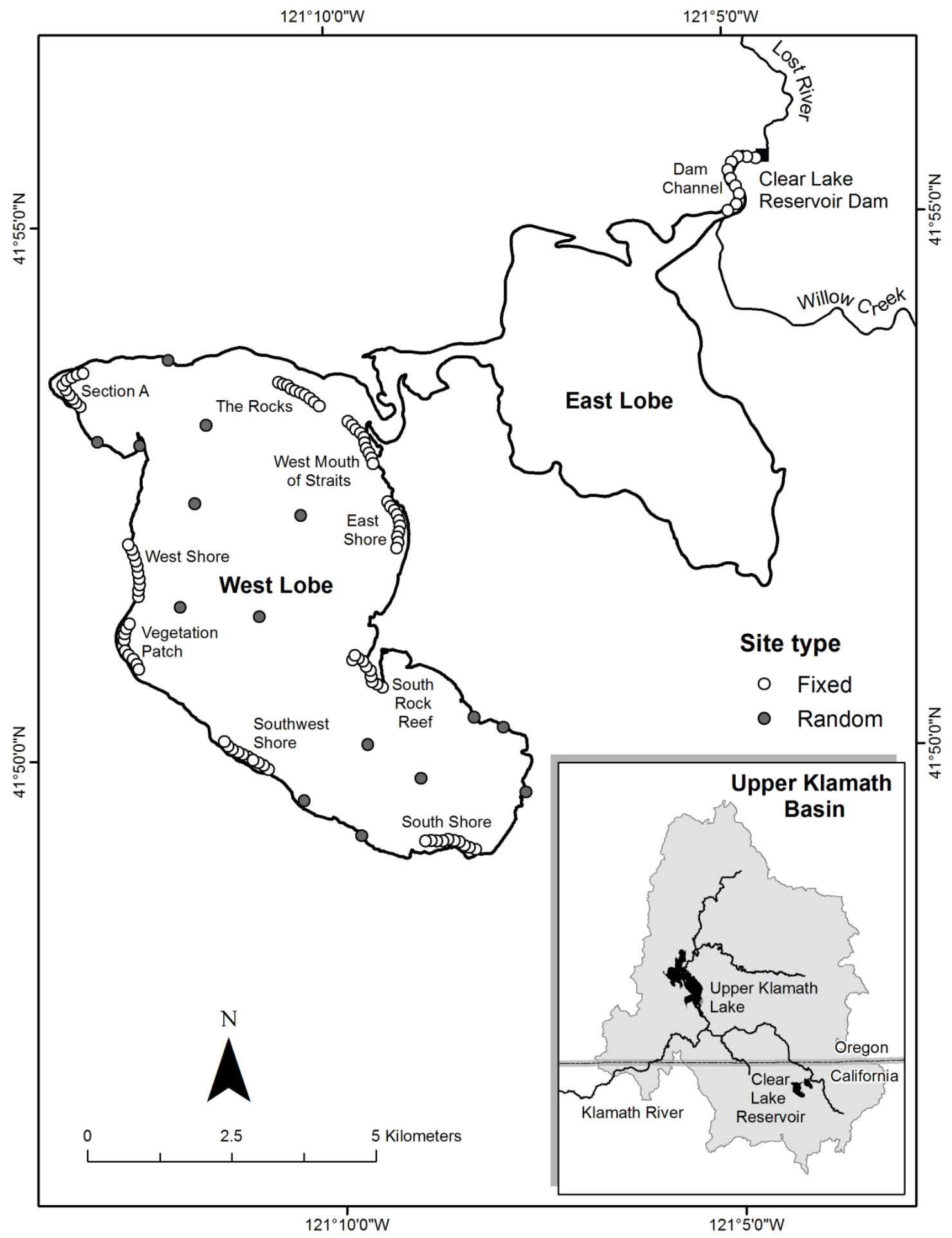

Figure 2. Locations of sample sites used to capture juvenile suckers in Clear Lake Reservoir, Modoc County, California, spring, summer, and fall 2015. 


\section{Fish Handling and Sampling}

Suckers were sampled with rectangular trap nets with mouth dimensions of $0.61 \times 0.91 \mathrm{~m}$, a 10 m-lead, and three internal fykes. Captured suckers were enumerated and measured for standard length (SL). The leading left pectoral fin ray was removed for aging all juvenile suckers (that is, individuals having a SL less than or equal to $300 \mathrm{~mm}$ ). A small (about $2 \mathrm{~mm}^{2}$ ) piece of tissue from the caudal fin was collected for genetic identification to taxa. Emaciation, deformities, macro parasites, petechial skin hemorrhaging, and gill abnormalities were systematically recorded. Other abnormalities and afflictions were noted when they were observed. Suckers were released at their site of capture.

\section{Aging Juvenile Suckers}

To estimate age, fin rays were mounted in epoxy, sectioned, and viewed by two experienced technicians under magnification using transmitted light. The number of annuli was first determined in blind reads, with each technician having no knowledge of the other's annuli count. When there was a discrepancy in the number of annuli, a third technician acted as a tie breaker or technicians examined fin rays together to reach consensus. The consensus reads were used in analyses.

\section{Species Identification}

To identify juvenile suckers collected in 2015 to taxa, we applied genetic identification methods described by Hoy and Ostberg (2015). Markers that have been identified cannot distinguish shortnose suckers from co-occurring Klamath largescale suckers. Previous studies that used morphological identification indicate that Klamath largescale suckers make less than 10 percent of age- 0 juvenile suckers captured in Upper Klamath Lake and Clear Lake Reservoir (Burdick and others, 2008, 2009; Burdick and Brown, 2010). Throughout this report, we call the non-Lost River sucker taxa shortnose suckers, although we acknowledge they are likely a combination of both shortnose and Klamath largescale suckers. Caudal fin tissue was collected and dried from all juvenile suckers. Deoxyribonucleic acid (DNA) was extracted from the caudal tissues using DNeasy kits (Qiagen, Inc. ${ }^{\circledR}$, Valencia, California). A total of 18 nuclear DNA TaqMan ${ }^{\circledR}$ assays that differentiate the species based on single nucleotide polymorphisms (SNPs) were used (Hoy and Ostberg, 2015, table 1). A mitochondrial DNA (mtDNA) TaqMan ${ }^{\circledR}$ assay also was applied to identify the maternal lineage (Lost River or shortnose sucker) for each individual (Hoy and Ostberg, 2015).

We used the program STRUCTURE, version 2.3 (Pritchard and others, 2000; Evanno and others, 2005), to probabilistically assign individual multilocus genotypes to the sampled juvenile suckers based on the posterior distribution of the program output. STRUCTURE uses a Markov chain Monte Carlo (MCMC) simulation approach to identify the posterior probability (q) for the proportion of an individual genotype derived from each of K population clusters. We applied the admixture model with independent allele frequencies, given the high differentiation between Lost River and shortnose suckers. A total of 10 repetitions were run in STRUCTURE, and the model parameters were as follows: (1) markers assumed to be unlinked; (2) 18 nuclear loci; (3) two populations assumed; and (4) 50,000 burn-in steps, followed by 100,000 MCMC iterations. We followed the procedure of Evanno and others (2005) to estimate the most probable number of K population clusters. The most probable number of population clusters was $\mathrm{K}=2$ (that is, Lost River and shortnose suckers). Therefore, admixture proportions between Lost River and shortnose suckers were estimated for each individual using the mean posterior probability over the 10 repetitions. 
We describe the probability of species assignment as a Lost River sucker (Prob[LRS]) among sample sites. However, it was more convenient for all other analyses to assign a species. In these cases, we called suckers having a Prob[LRS] $\geq 0.95$ a Lost River sucker and those with a Prob [LRS] $\leq 0.05$ a shortnose sucker.

\section{Indices of Juvenile Sucker Production and Survival}

We calculated indices of relative (among cohorts, species, and lakes) production in each lake and seasonal age-0 survival in Upper Klamath Lake. Two indices of annual age-0 production were calculated; (1) the percentage of August nets to catch one or more age-0 sucker and (2) the mean catch per unit effort of age- 0 suckers in August sampling. We calculated the ratio of mean age- 0 sucker catch rates between the August and September sampling seasons of 2015 in Upper Klamath Lake as rough index of relative apparent survival.

Apparent annual survival was calculated for suckers born from 2010 to 2012 in Clear Lake Reservoir using a catch-at-age approach and data collected from 2012 to 2015 (Allen and Hightower, 2010). Data collected prior to 2015 that were used in this analysis is published in Burdick and Rasmussen (2012, 2013) and Burdick, Elliott, and others (2015). These data were collected using identical gear and protocol as described in this report for 2015. Based on a lack of spatial patterning among species and age classes of suckers in Clear Lake Reservoir in 2015, we presumed samples collected in previous years were representative of the species and age of juvenile sucker populations in this lake (Burdick and Rasmussen, 2012). Cohorts of suckers born from 2010 to 2012 were selected for analysis because we have 4 consecutive years of catch-at-age data for them, the minimum number of data points required for good trend estimation (Allen and Hightower, 2010). We used an exponential decay model to calculate and index of survival in the form of $S=e-M$, where $S$ is annual survival and $M$ is the instantaneous rate of natural mortality. To calculate $\mathrm{M}$, we fit the linear model $\ln (\mathrm{CPUE})=\mathrm{a}+\mathrm{M}^{*}$ (age) in program $\mathrm{R}$ using the base package (R Core Team, 2013). For these analyses both sucker taxa were combined, because taxa were not distinguished for all captured suckers prior to 2014. Based on genetic species composition data collected in 2014 and 2015, suckers captured in all years were presumed to be predominantly shortnose suckers (Burdick, Elliott, and others, 2015).

Several assumptions are important for meaningful interpretation of catch-at-age data as indices of survival. First we assumed that age and species distributions in our fixed sampling were representative of the populations throughout each lake. To evaluate the validity of this assumption, we compared age and species composition of suckers captured in fixed and randomly selected sample sites and among sampling areas in 2015. We also assumed that age selectivity of the sampling equipment was consistent among sampling periods and that mortality due to our sampling was negligible. Finally, we assumed that mortality was constant among years for a given year class. Because larger suckers may be more likely to avoid trap nets, we continue to use the conservative approach for presenting our calculations as relative (among year class) indices of juvenile sucker survival rather than estimates of true survival. 


\section{Apparent Growth and Summary of Afflictions}

We summarize daily growth rates and the prevalence of afflictions as a way to crudely evaluate relative condition of suckers between the two lakes and the two taxa. First, we estimated apparent daily age-0 sucker growth in Upper Klamath Lake using linear regression for each sucker taxa. We also report the length-at-age of older suckers captured in Clear Lake Reservoir. We report the prevalence of external afflictions on all age classes of suckers combined. We pay special attention to those afflictions that are either common or potentially associated with mortality (Markle and others, 2014; Burdick, Elliott, and others, 2015). These included petechial hemorrhaging of the skin, opercular deformities, black spots (presumed to be encysted metacercariae of trematodes), and Lernaea spp.

\section{Results}

\section{Sucker Species and Age Composition}

A total of 197 fin ray sections were examined by two independent readers to determine the number of annuli present. Fin ray sections from two fish from Upper Klamath Lake were of poor quality, and the number of annuli could not be determined. The two initial readers disagreed on the number of annuli for 10 percent of fin rays examined. In all cases, the discrepancy in estimated age was a single year. The reader with the greater annuli count varied, indicating there was not a systematic bias in the discrepancy between reads.

A total of 175 juvenile suckers were captured from Upper Klamath Lake in 2015, and 92 percent of these had no fin ray annuli and were considered to be age- 0 . We also captured 12 suckers with one annuli on fin rays (age-1) and 1 sucker with three annuli on fin ray (age-3). Of these suckers, 47 percent were likely shortnose suckers, 30 percent were likely Lost River suckers, and the remainder were not assigned to species, based on our criteria. Our August age-0 sucker sample $(n=119)$ was comprised of 33 percent Lost River suckers, 42 percent shortnose suckers, and 25 percent with uncertain species identification. This is in contrast to our September age-0 sucker sample $(n=21)$, in which only 12 percent were likely Lost River suckers, 68 percent were likely shortnose suckers, and 20 percent had unknown species identification. Of the 12 age-1 suckers captured from Upper Klamath Lake in 2015, 7 were shortnose suckers and 1 was a Lost River sucker. Of the other four, three had Prob[LRS] from 0.11 to 0.23 , indicating that they were more likely shortnose suckers than Lost River suckers.

A total of 24 suckers were captured from Clear Lake Reservoir in 2015. Suckers captured in Clear Lake Reservoir were approximately equally distributed between age- 2 and age-6. The Prob[LRS] of the 24 suckers captured from Clear Lake Reservoir was 0.01, indicating that these fish were either shortnose or Klamath largescale suckers. 


\section{Capture Efficiency and Size Selectivity}

We captured, fin clipped, and released a total of 179 individual suckers in Barkley Springs in Hagelstein Park (table 3). These fish ranged in length from 71 to $236 \mathrm{~mm}$ SL. A total of 137 of the sucker captured in Barkley Springs in 2015 were identified using genetic markers. Totals of 72 percent were shortnose suckers, 2 percent were Lost River suckers, and the others were unidentified suckers based on our species assignment criteria. Between zero and four fin ray annuli were identified on a subsample of 38 suckers, and 53 percent had a single fin ray annuli (presumed age-1). Median standard length increased with age, as expected (fig. 3). We recaptured 27 fin-clipped suckers within the week in which they were marked. Recapture rates were low in the 90 to $129 \mathrm{~mm}$ SL size range (5 recaptured of 102 marked). The highest recapture rates occurred in the 210-229 mm SL size class (6 recaptured of 11 marked) but the sample size was small (fig. 4). The non-size specific capture efficiency of a known number of marked suckers in Barkley Springs ranged from 0 to 20 percent, with a mean of 8 percent ( $\mathrm{SD}=7$ percent) of available fish being recaptured on any one occasion (table 3 ).

Table 3. Number of marked suckers available for capture and recaptured by sampling date from Barkley Springs in Hagelstein Park, Oregon.

[Number of fish that were marked during the sampling week and at large during a particular day of sampling were considered to be available for capture. Fish marked in previous weeks of sampling were not counted as available for capture because their fate was unknown. SD, standard deviation]

\begin{tabular}{lccc}
\hline \multicolumn{1}{c}{ Date } & $\begin{array}{c}\text { Available for } \\
\text { capture }\end{array}$ & Recaptured & $\begin{array}{c}\text { Proportion } \\
\text { recaptured }\end{array}$ \\
\hline $5 / 21 / 2015$ & 5 & 1 & 0.20 \\
$5 / 22 / 2015$ & 10 & 0 & 0.00 \\
$5 / 23 / 2015$ & 16 & 1 & 0.06 \\
\hline $7 / 29 / 2015$ & 21 & 0 & 0.00 \\
$7 / 30 / 2015$ & 32 & 2 & 0.06 \\
$7 / 31 / 2015$ & 49 & 5 & 0.10 \\
\hline $9 / 23 / 2015$ & 41 & 2 & 0.05 \\
$9 / 24 / 2015$ & 64 & 10 & 0.16 \\
$9 / 25 / 2015$ & 116 & 5 & 0.04 \\
\hline Mean & 39 & 2.9 & 0.08 \\
SD & 35 & 3.3 & 0.07 \\
\hline
\end{tabular}




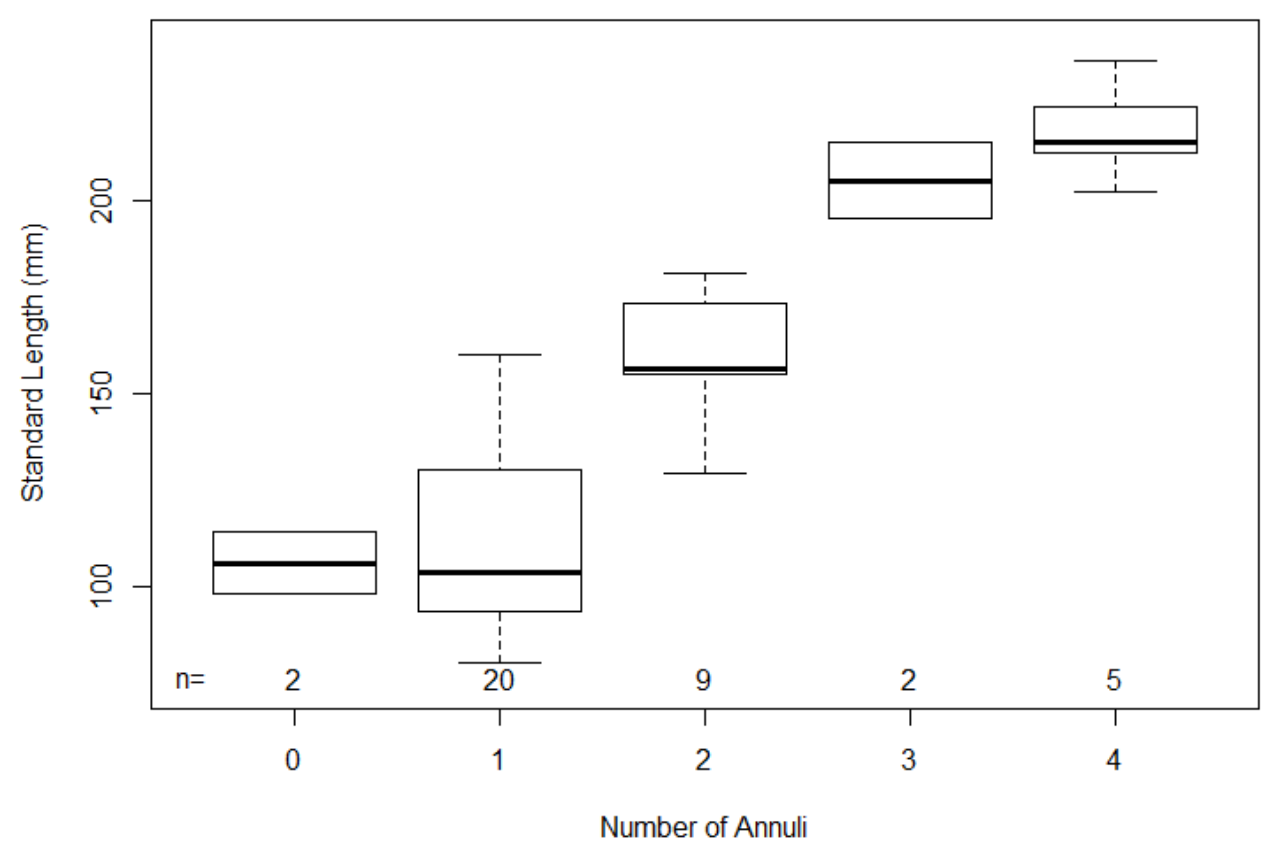

Figure 3. Number of annuli on fin ray sections and corresponding standard length (millimeter) for 38 suckers collected from Barclay Springs in Hagelstein Park, Oregon. The number of annuli is presumed to correspond to age in years of suckers. Whiskers indicate the 5th and 95th percentiles. Boxes indicate the 25th and 75th percentiles, and the line indicates the median. The numbers of data points (n) used to make each boxplot are given along the top of the $x$-axis.

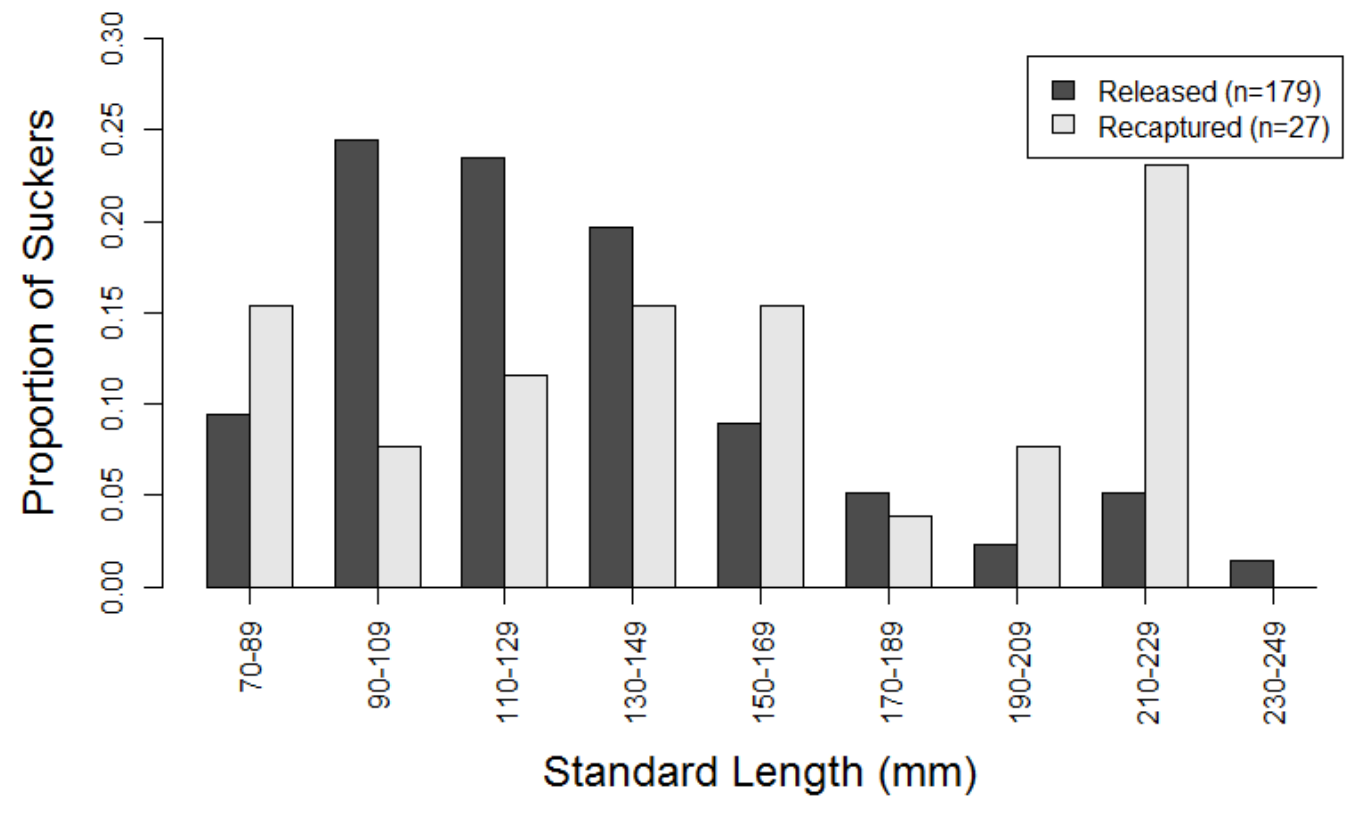

Figure 4. Proportional catch by 20 millimeter standard length grouping of suckers in Barkley Springs in Hagelstein Park, Oregon. Proportions are separately calculated and shown for marked and recaptured suckers. Suckers were sampled the weeks of May 21, July 29, and September 23, 2015. 


\section{Evaluation of Assumptions for Survival Analyses}

We compared catches at fixed and randomly selected sites sampled in 2015 to determine whether fixed sample sites resulted in a sample with species and age composition representative of the populations. Our catch rates and numbers of suckers captured were sufficient to make this comparison for only the August 2015 sampling period in Upper Klamath Lake. During the August sample period, single catches ranged from 0 to 20 suckers, with the largest catch occurring at the Fish Banks North site on August 11, 2015 (table 4). There was no difference in the distribution of ages or among species between random and fixed sites in August (tables 5 and 6). Too few age-1 or older suckers were captured to evaluate their distribution among specific sample locations. Lost River Suckers comprised most of age-0 sucker catches at the Offshore Hagelstein (six of seven) and the Hanks Marsh (six of eight) sites. Shortnose suckers comprised most of the catch at the Fish Banks North and Moore Park sites (fig. 5). At all other sites where age-0 suckers were captured, both species were approximately equally represented.

Table 4. Number of trap nets and catch statistics by area sampled, Upper Klamath Lake, Oregon, August 2015.

[Total number of suckers captured, maximum catch per net, and percentage of nets to catch one or more suckers are given by presumed age class. Age classes were estimated based on the number of annuli on fin ray sections]

\begin{tabular}{l|c|cc|cc|cr}
\hline \multirow{2}{*}{ Area } & \multirow{2}{*}{$\begin{array}{c}\text { Number } \\
\text { of nets }\end{array}$} & \multicolumn{2}{c|}{ Total number of suckers } & \multicolumn{2}{c|}{ Maximum catch } & \multicolumn{2}{c}{ Percent non-zeros } \\
\cline { 3 - 8 } & & Age-0 & Age-1 & Age-0 & Age-1 & Age-0 & Age-1 \\
\hline Wood River Wetland & 8 & 0 & 0 & 0 & 0 & 0 & 0 \\
Fish Banks north & 10 & 47 & 1 & 20 & 1 & 60 & 10 \\
Fish Banks south & 10 & 18 & 0 & 5 & 0 & 30 & 0 \\
Pelican Bay & 10 & 7 & 0 & 2 & 0 & 20 & 0 \\
Tulana & 10 & 2 & 0 & 1 & 0 & 10 & 0 \\
Shoalwater Bay & 10 & 12 & 0 & 6 & 0 & 40 & 0 \\
Hagelstein (in lake) & 10 & 7 & 0 & 3 & 0 & 30 & 0 \\
Howard Bay & 10 & 0 & 0 & 0 & 0 & 0 & 0 \\
Hanks Marsh & 10 & 6 & 0 & 2 & 0 & 20 & 0 \\
Moore Park & 10 & 16 & 2 & 3 & 1 & 30 & 20 \\
Random & 20 & 17 & 1 & 6 & 1 & 20 & 5 \\
\hline
\end{tabular}


Table 5. Proportion of catch (number of individual fish) by number of annuli on fin ray section (presumed age) of suckers captured in fixed and randomly selected sites during three sampling periods, Upper Klamath Lake, Oregon, 2015.

[Numbers of fish captured in each sampling period are given in the last line of data. $3+$ annuli means there were three or more annuli identified on the fin ray]

\begin{tabular}{c|ccc|ccc}
\hline \multirow{2}{*}{ Annuli } & \multicolumn{3}{c|}{ Fixed } & \multicolumn{3}{c}{ Random } \\
\cline { 2 - 7 } & June & August & September & June & August & September \\
\hline 0 & 0.000 & 0.966 & 1.000 & 0.000 & 0.944 & 0.800 \\
1 & 0.875 & 0.025 & 0.000 & 0.000 & 0.056 & 0.200 \\
2 & 0.125 & 0.000 & 0.000 & 0.000 & 0.000 & 0.000 \\
$3+$ & 0.000 & 0.008 & 0.000 & 0.000 & 0.000 & 0.000 \\
\hline $\mathrm{n}$ & 8 & 119 & 21 & 0 & 18 & 5 \\
\hline
\end{tabular}

Table 6. Proportion of catch (number of individual fish) by species in fixed and randomly selected sampling sites during three sampling periods, Upper Klamath Lake, Oregon, 2015.

[SNS, shortnose sucker or probability of species assignment as LRS of $\leq 0.05$; LRS, Lost River sucker or probability of being a Lost River sucker of $\geq 0.95$; Other, Probability of being a Lost River sucker of $>0.05$ and $<0.95]$

\begin{tabular}{l|ccc|ccc}
\hline \multirow{2}{*}{ Species } & \multicolumn{3}{c|}{ Fixed sites } & \multicolumn{3}{c}{ Random sites } \\
\cline { 2 - 7 } & June & August & September & June & August & September \\
\hline SNS & 0.50 & 0.42 & 0.62 & 0.00 & 0.33 & 1.00 \\
LRS & 0.00 & 0.32 & 0.14 & 0.00 & 0.44 & 0.00 \\
Other & 0.50 & 0.26 & 0.24 & 0.00 & 0.22 & 0.00 \\
\hline $\mathrm{n}$ & 8 & 119 & 21 & 0 & 18 & 5 \\
\hline
\end{tabular}



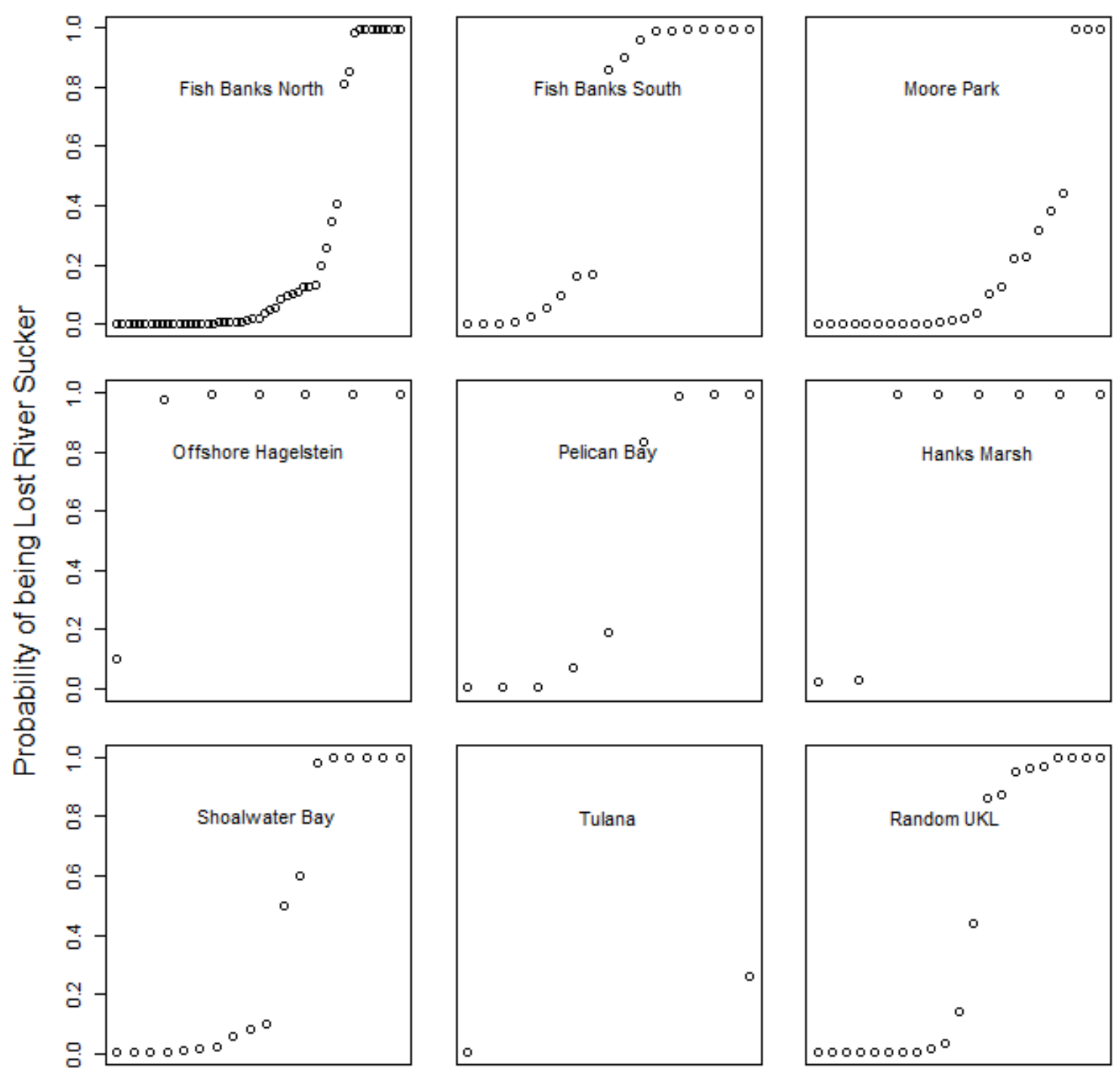

Individual Sucker

Figure 5. Probability of species assignment based on STRUCTURE for age-0 juvenile suckers shown for nine sites sampled, Upper Klamath Lake, Oregon, 2015. Site locations are shown in figure 1, and the numbers of nets set for each of these sites are given in table 1. Age-0 suckers were not captured at two (Howard Bay and Wood River Wetland) of 11 sites sampled and therefore are not included in this figure. 


\section{Juvenile Sucker Production and Survival}

We detected production of a 2015 year class for both Lost River sucker and shortnose sucker in Upper Klamath Lake, but no age-0 suckers were captured in Clear Lake Reservoir. In Upper Klamath Lake, no age- 0 suckers were captured in June and the percentage of nets to capture one or more age- 0 sucker and mean catch rates decreased from August to September 2015 (table 7). Mean catch rates decreased by 89 percent for Lost River suckers and by 50 percent for shortnose suckers between August and September in Upper Klamath Lake (table 7).

Table 7. Percentage of nets and mean catch to catch one or more age-0 sucker in Upper Klamath Lake, Oregon, August and September 2015.

[Species were assigned based on a STRUCTURE output as Lost River sucker (Prob[LRS] $\geq 0.95$ ) or shortnose sucker $($ Prob $[\mathrm{LRS}] \leq 0.05)$. Totals in this table include Lost River suckers, shortnose suckers, and suckers that had STRUCTURE assignment probabilities that fell between 0.50 and 0.95 . The mean and standard deviation of age- 0 sucker catch rates (suckers captured per net) are given]

\begin{tabular}{lcc|cc}
\hline \multirow{2}{*}{ Species } & \multicolumn{2}{c|}{ August } & \multicolumn{2}{c}{ September } \\
\cline { 2 - 5 } & Percent & Mean (士 SD) & Percent & Mean (士 SD) \\
\hline Lost River Sucker & 23 & $0.38(0.78)$ & 4 & $0.04(0.20)$ \\
Shortnose Sucker & 19 & $0.48(1.39)$ & 21 & $0.24(0.49)$ \\
Total & 42 & $1.18(2.58)$ & 26 & $0.37(0.76)$ \\
\hline
\end{tabular}

Annual survival indices for the 2010 through 2012 cohorts in Clear Lake Reservoir, as generated from catch-at-age analysis using data collected from 2012 to 2014, were similar and ranged from 0.37 $(\mathrm{SE} \pm 0.06)$ to $0.44(\mathrm{SE} \pm 0.08)$ percent among three year classes in Clear Lake Reservoir (table 8). Rsquared values for these estimates were 0.91 or greater indicating strong line fit (fig. 6). 


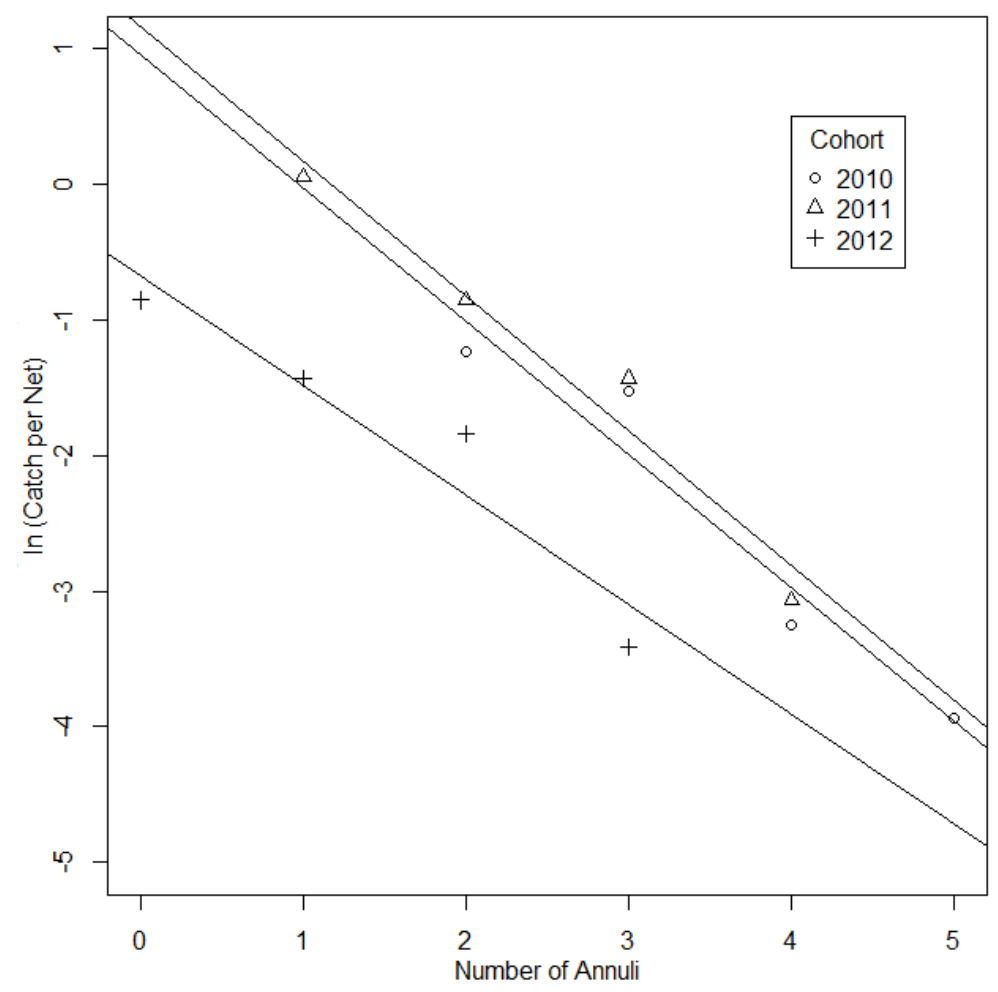

Figure 6. Natural log of the catch per net of suckers by the number of annuli on fin rays (presumed age) for 3 year classes captured in Clear Lake Reservoir, California. Lines indicate the model fit line used in apparent annual relative survival estimates.

Table 8. Index of instantaneous rate of apparent natural mortality (M) and annual apparent survival (S) for three cohorts of suckers captured in Clear Lake Reservoir, California.

[The fit statistics (r2) and sample sizes (n) for each year class are given]

\begin{tabular}{ccccc}
\hline Year class & $\mathbf{n}$ & $\mathbf{M}$ & \multicolumn{1}{c}{$\mathbf{S}$} & $\mathbf{R}^{\mathbf{2}}$ \\
\hline 2010 & 117 & $0.98(0.19)$ & $0.38(0.070)$ & 0.93 \\
2011 & 409 & $1.00(0.15)$ & $0.37(0.06)$ & 0.95 \\
2012 & 203 & $0.81(0.18)$ & $0.44(0.08)$ & 0.91 \\
\hline
\end{tabular}




\section{Apparent Growth}

Mean ( \pm SD) standard length of age-0 Lost River suckers was $63.8 \mathrm{~mm} \mathrm{SL}( \pm 6.3, \mathrm{n}=45)$ in our August sample and $81.0( \pm 8.0, \mathrm{n}=3) \mathrm{mm}$ SL in our September sample from 2015. On average $( \pm \mathrm{SE})$, age-0 Lost River sucker length increased by $0.72\left( \pm 0.01, \mathrm{R}^{2}=0.44\right) \mathrm{mm}$ SL per day during this time (fig. 7). Mean $( \pm \mathrm{SD})$ standard length of age-0 shortnose suckers was $49.6 \mathrm{~mm} \mathrm{SL}( \pm 6.5, \mathrm{n}=57)$ in our August sample and $72.2( \pm 6.5, \mathrm{n}=17) \mathrm{mm}$ SL in our September sample from 2015. On average ( \pm SE) age-0 shortnose sucker length increased by $0.57\left( \pm 0.04, \mathrm{R}^{2}=0.75\right) \mathrm{mm}$ SL per day (fig. 7).

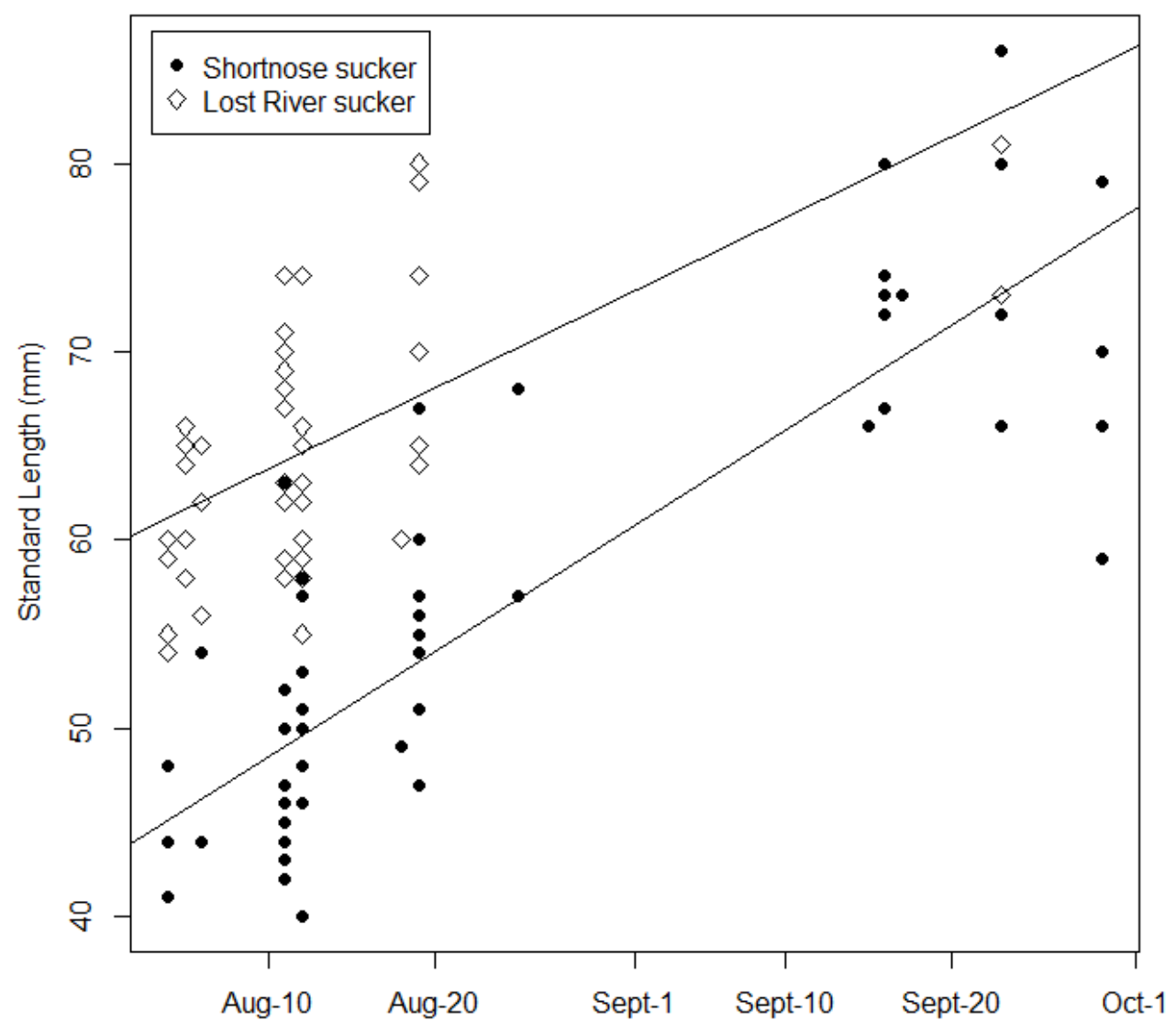

Figure 7. Standard length by day of the year for shortnose suckers and Lost River suckers with one annuli on fin rays (presumed age-0) captured in Upper Klamath Lake, Oregon, 2015. 
Juvenile suckers from Upper Klamath Lake with one fin-ray annulus were approximately twice as long as those with no annulus (fig. 8). The one age-1 Lost River sucker captured from Upper Klamath Lake in 2015 was $113 \mathrm{~mm}$ SL. Age-1 shortnose suckers from Upper Klamath Lake ranged from 89 to $158 \mathrm{~mm}$ SL. There was no clear difference in lengths between age classes of shortnose suckers from Clear Lake Reservoir. Age-2 to age-6 suckers ranged from a $164 \mathrm{~mm}$ SL fish that had five annuli to a $300 \mathrm{~mm}$ SL fish that had three annuli (fig. 9).

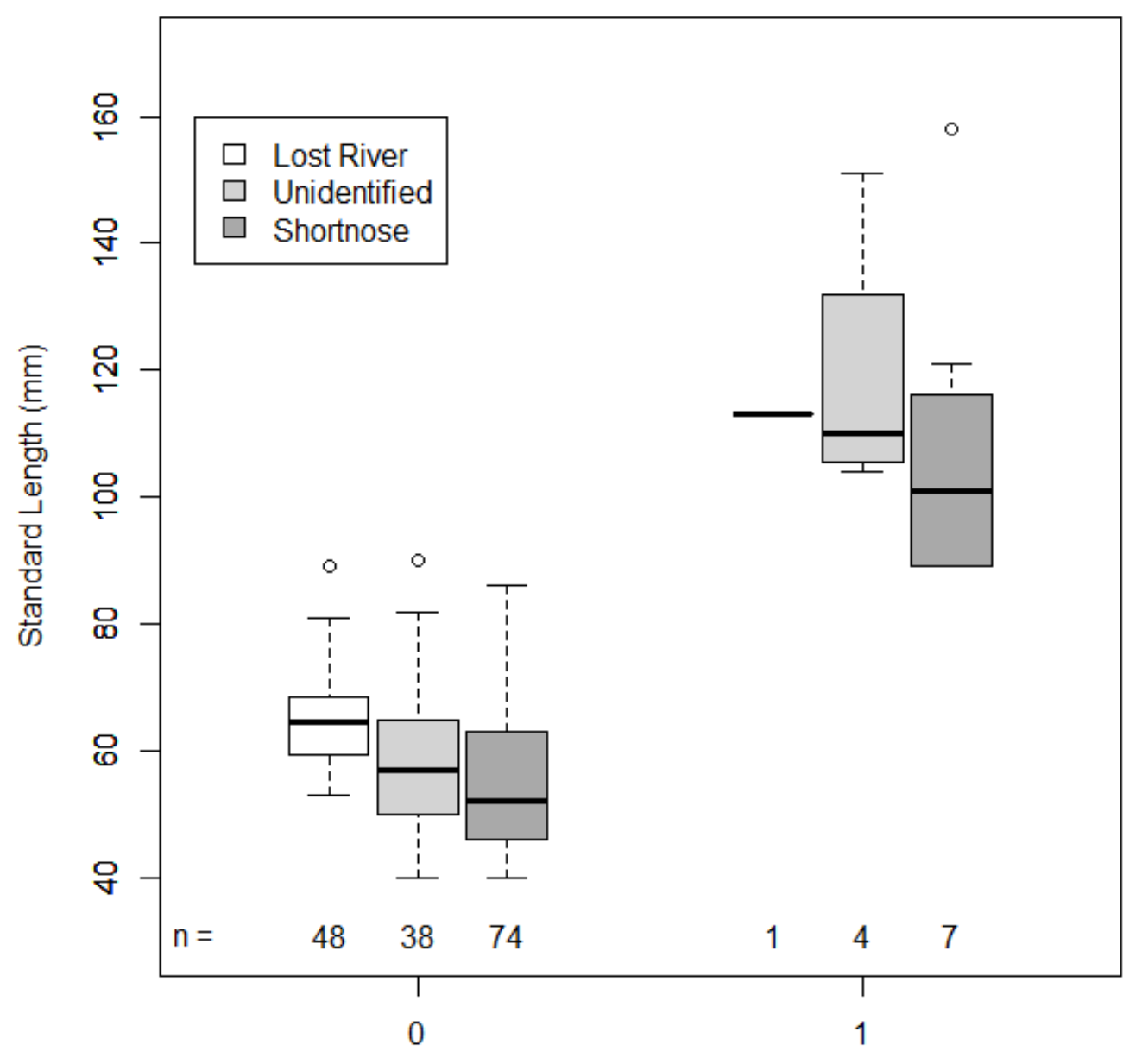

Number of Annuli

Figure 8. Standard length and the number of annuli on fin ray sections from 172 suckers captured from Upper Klamath Lake, Oregon, 2015. Circles indicate outliers. Whiskers indicate the 5th and 95th percentiles. Boxes indicate the 25th and 75th percentiles, and the line indicates the median. The numbers of data points (n) used to make each boxplot are given along the top of the $x$-axis. 


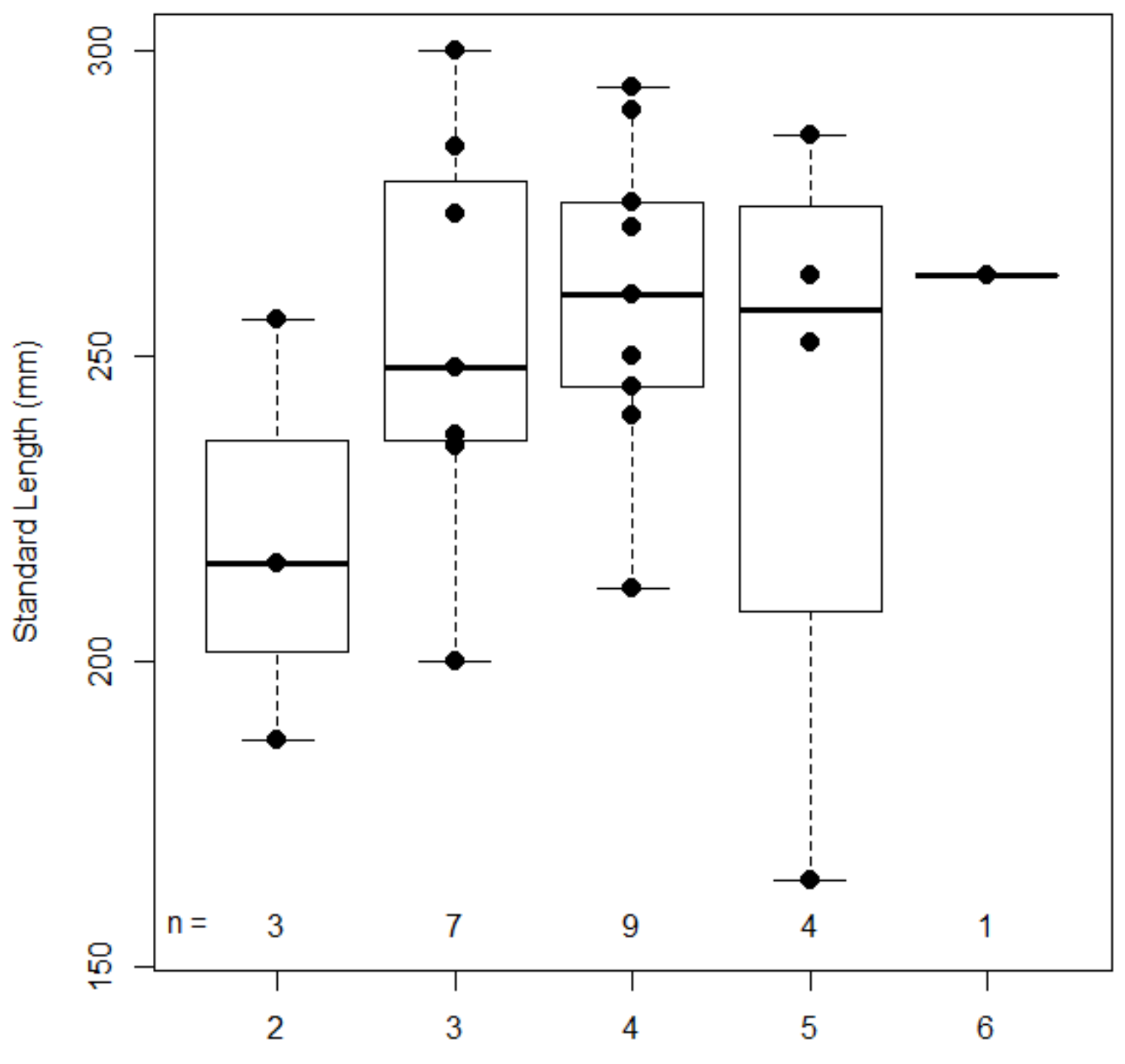

Number of Annuli

Figure 9. Standard length and number of annuli on fin ray sections from all 24 suckers captured in trap nets from Clear Lake Reservoir, California, 2015. Points show all measurements whereas boxplots are shown to summarize data. Whiskers indicate the 5th and 95th percentiles. Boxes indicate the 25th and 75th percentiles, and the line indicates the median. The sample sizes $(n)$ used to create each box are given above the $x$-axis. 


\section{Afflictions}

Lernaea spp. parasitized age- 0 and age- 1 suckers captured in 2015 . Of the age- 0 suckers collected from Upper Klamath Lake, 39 percent of Lost River suckers, 37 percent of suckers with intermediate Prob[LRS], and only 11 percent of age-0 shortnose suckers had Lernaea spp. A total of 33 percent of shortnose suckers ages 2-6 collected from Clear Lake Reservoir had one or more Lernaea spp. The number of Lernaea spp. per fish ranged from 0 to 11.

Petechial hemorrhages of the skin were common in suckers collected from Upper Klamath Lake but were observed on only one sucker captured in Clear Lake Reservoir. In Upper Klamath Lake in 2015, the affliction was noted for 43 percent of age-0 Lost River Suckers, 38 percent of age-0 suckers of undetermined taxa, and only 24 percent of age- 0 shortnose suckers. The prevalence of petechial hemorrhages of the skin decreased on age- 0 suckers in Upper Klamath Lake from 39 percent to 7 percent between August and September sampling periods.

Deformed opercula and black spots were observed on suckers from Upper Klamath Lake but not Clear Lake Reservoir. Deformities of the opercula were observed in 5 percent of suckers from Upper Klamath Lake and 0 percent of suckers from Clear Lake Reservoir in 2015. When deformities occurred they exposed nearly all of the gill filaments on one of both sides of the fish. Opercular deformities appeared in both taxa and were only observed on age- 0 suckers in 2015 . Black spots were visible on the exterior of 5 percent of both sucker taxa captured from Upper Klamath Lake in August of 2015. These spots were not observed on suckers collected in June or September from Upper Klamath Lake, or from Clear Lake Reservoir in any month. Other afflictions, each observed in no more than 5 individual suckers in 2015 all from Upper Klamath Lake, included damaged and deformed fins, eyes with hemorrhages or exophthalmia, attached lamprey, and skin injuries.

\section{Discussion}

\section{Capture Efficiency and Size Selectivity}

Our mark-recaptured experiment in Barkley Springs provides some information on capture efficacy and size selectivity of suckers in trap nets. If there was gear bias at all it was in the direction of favoring larger and older rather than smaller and younger suckers within the range that we captured. We captured suckers up to $236 \mathrm{~mm}$ SL, demonstrating that our gear doesn't exclude suckers of this size. Based on the size of the sub-set of aged suckers (fig. 3), age-1 suckers probably made up the majority of marked suckers, whereas age- 3 and age-4 most likely made up the majority of recaptured suckers.

Application of this information to our monitoring study is limited for several reasons. First, the sizes of fish captured in this study are not representative of size distributions of suckers captured in either lake. Seventy-five percent of suckers captured in Upper Klamath Lake were smaller than the smallest sucker in the Barkley Springs experiment, and 92 percent of suckers captured in Clear Lake were larger than $200 \mathrm{~mm}$ SL. Second, fish may avoid nets after their initial capture and marking, resulting an underestimate of capture efficacy for unmarked fish. Finally, trap net avoidance depends on water clarity (Hubert and others, 2012). Water clarity in Barkley Springs is much better than either lake during the summer. 
There are two ways to estimate size and age selectivity in fish populations. We attempted to estimate selectivity using recaptures of a known size distribution of suckers in a closed system (Hamley and Regier, 1973). The approach was only moderately successful due to a small sample size and a limited size range in the spring. The other commonly used method to estimate relative selectivity is to compare the lengths or ages of fish captured in several types of gear (for example, Clavero and others, 2006). Gear selectivity evaluations could be accomplished by fishing multiple gear types at the same time in Clear Lake Reservoir in a year when multiple age classes of suckers are present.

\section{Evaluation of Assumptions for Survival Analyses}

Given the balanced species distribution among fixed sites and the lack of difference in species and age composition between fixed and randomly selected sites, we presume our sampling was representative of the populations in Upper Klamath Lake. In the future, more nets need to be fished at randomly selected sites to provide conclusive evidence about this. We were unable to determine if fixed sites provided a biased age or species distribution in June and September sample seasons in Upper Klamath Lake and all sample seasons in Clear Lake Reservoir due to small catches of juvenile suckers.

Declining catch rates of age- 0 suckers in Upper Klamath Lake can be attributed to high rates of mortality rather than emigration from sampling areas or decreased capture efficiency for older suckers. Hendrixson, Burdick, Herring, and others (2007) found no evidence of migration patterns for age-0 juvenile suckers in Upper Klamath Lake of either taxa from July to the end of August or early September. Capture of larger juvenile suckers in Barkley Springs and in Clear Lake Reservoir using the same gear as we used in Upper Klamath Lake indicated that a reduction in selectivity of larger older suckers is unlikely to completely explain summer time decreases in catches.

\section{Juvenile Sucker Production and Survival}

The percentage of nets that captured an age- 0 sucker and mean catch rate of age- 0 suckers in Upper Klamath Lake in 2015 are similar to published values for the combination of taxa in this lake. A total of 42 percent of nets set in August captured at least one age-0 sucker (table 7). Previous studies have shown that the percentages of nets catching one or more age-0 sucker in August in Upper Klamath Lake range from around 20 to 83 (Hendrixson, Burdick, Herring, and others, 2007; Hendrixson, Burdick, VanderKooi, and others, 2007;Burdick and others, 2008; Bottcher and Burdick, 2010; Burdick and Brown, 2010; Burdick and VanderKooi, 2010; Burdick and Hewitt, 2012; Burdick, Elliott, and others, 2015). Additionally, mean August age-0 catch rates in Upper Klamath Lake range from around 0.3 to 3.0 in most years. The exception occurred in August of 2006 when mean catch rate was $79( \pm 177)$ suckers per trap net set and catch per net was an order of magnitude higher than during any other August in USGS trap net data (Burdick and others, 2008).

Declining summer time catch rates and a low abundance of older juvenile suckers in Upper Klamath Lake indicate mortality may be greater for Lost River Suckers than for Shortnose Suckers. The percentage of nets to catch one or more age- 0 suckers and mean catch rates of age- 0 suckers declined more for Lost River Suckers than Shortnose Suckers between August and September Samples. Age-0 suckers of both taxa were captured in nearly equal proportions in Upper Klamath Lake in 2014 (Burdick, Elliott, and others, 2015), but there seven times as many age-1 Shortnose Suckers as age-1 Lost River Suckers in our 2015 catches. 
In contrast to Upper Klamath Lake, no age-0 suckers were captured from Clear Lake Reservoir in 2015 (this report) or in 2014 (Burdick, Elliott, and others, 2015). Age-0 suckers have not been detected in Clear Lake Reservoir since 2013 (Burdick and Rasmussen, 2013; Burdick, Elliott, and others, 2015). Mean August age-0 sucker catch rates reported between 2011 and 2013 in Clear Lake Reservoir range from 0.1 to 0.4 (Burdick and Rasmussen, 2012, 2013; Burdick, Elliott, and others, 2015). The percentage of nets to capture one or more age- 0 sucker in August ranged from 8 (in 2013) to 27 (in 2012) (Burdick and Rasmussen, 2012, 2013).

A lack of age- 0 suckers captured in recent years in Clear Lake Reservoir is consistent with the observation that water flows in Willow Creek during spawning season play a critical role in the production of age-0 suckers. For example, mean $( \pm \mathrm{SD})$ gage height in Willow Creek were relatively low during the spring spawning seasons (February-April) of $2014(41.0 \pm 0.8 \mathrm{ft})$ and $2015(41.0 \pm 0.9 \mathrm{ft})$ compared to 2013 (42.0 $\pm 0.8 \mathrm{ft}$; Bureau of Reclamation, written commun., unpublished data for Willow Creek gage, 2016). The numbers of PIT tagged adult suckers detected in Willow Creek were 1,202 in 2013, 6 in 2014, and 36 in 2015 (D. Hewitt, U.S. Geological Survey, oral commun. 2016). More than 1,000 PIT tagged adult suckers were likely to be alive in the Clear Lake populations in each of these years, but the exact numbers are unknown. Thus, years with low flow coincide with years of no age- 0 sucker captures.

We produced the first index of apparent annual relative survival for juvenile Lost River and shortnose suckers in Clear Lake Reservoir. Given the data available, it is a non-species specific index. Improvement of this index will depend on obtaining estimates of size and age selectivity of gear and species identification on all fish captured in at least 2 more years. Nevertheless, when compared to Upper Klamath Lake populations, where catches of suckers older than age-1 are near zero, sucker survival in Clear Lake Reservoir is relatively high.

\section{Apparent Growth}

Apparent growth rates and September sizes of age-0 Lost River and shortnose suckers in 2015 were similar to previously reported rates and sizes in Upper Klamath Lake. The 2015 growth rate for age-0 Lost River suckers of $0.72\left( \pm 0.01, \mathrm{R}^{2}=0.44\right) \mathrm{mm}$ SL per day is within the range $(0.33$ and 0.73 $\mathrm{mm}$ SL per day) of previously reported rates (Hendrixson, Burdick, Herring, and others, 2007; Hendrixson, Burdick, VanderKooi, and others 2007; Burdick and others, 2008; Burdick and Hewitt, 2012). The average standard length ( \pm SD) of age-0 Lost River suckers in Upper Klamath Lake in September $2015(81.0 \pm 8.0 \mathrm{~mm} \mathrm{SL})$ was slightly larger than previous reported values that range from 60 and $75 \mathrm{~mm}$ SL in September (Hendrixson, Burdick, Herring, and others, 2007; Hendrixson, Burdick, VanderKooi, and others, 2007; Burdick and others, 2008; Burdick and Hewitt, 2012). The 2015 age-0 shortnose sucker growth rate estimate of $0.57( \pm 0.04) \mathrm{mm}$ SL per day is only slightly faster than the range previously reported estimates $(0.33-0.51 \mathrm{~mm}$ SL per day). Previous studies reported that shortnose suckers averaged between 55 and $70 \mathrm{~mm}$ SL in September, which is only slightly smaller than the average (72.2 $\pm 6.5 \mathrm{~mm} \mathrm{SL}$ ) length of age-0 shortnose suckers in the 2015 September sample (Hendrixson, Burdick, Herring, and others, 2007; Hendrixson, Burdick, VanderKooi, and others, 2007; Burdick and others, 2008; Burdick and Hewitt, 2012). The 2015 sample period extended about 2 weeks longer into September than sampling in previous years, which may explain why average September lengths were slightly greater in 2015 compared to other years. 
Presumed age-0 suckers (having no apparent annuli on fin rays) that were collected in 2012 from Clear Lake Reservoir were larger but grew at similar rates (about $0.46 \mathrm{~mm}$ SL per day; $\mathrm{n}=66$ ) as presumed age-0 suckers without fin-ray annuli that were collected in Upper Klamath Lake in 2014 and 2015 (Burdick and Rasmussen, 2013; Burdick, Elliott, and others, 2015). Presumed age-0 suckers collected from Clear Lake Reservoir averaged ( \pm SD, sample size) $88( \pm 11.4, n=17) \mathrm{mm}$ SL in early July and $113( \pm 22, n=10)$ mm SL in mid-August of 2012 (Burdick and Rasmussen, 2013). These were only slightly smaller on average than apparent age-1 suckers collected in Clear Lake Reservoir or in Upper Klamath Lake in any year to date (Hendrixson, Burdick, Herring, and others, 2007; Hendrixson, Burdick, VanderKooi, and others, 2007; Burdick and others, 2008; Burdick and Hewitt, 2012; Burdick and Rasmussen, 2013; Burdick, Elliott, and others, 2015).

The difference in size of apparent age- 0 suckers between Clear Lake Reservoir and Upper Klamath Lake has several possible explanations. Age-0 Clear Lake Reservoir suckers may reach a larger size earlier in the year due to earlier hatch and drift timing than in Upper Klamath Lake (Ellsworth and Martin, 2012; Sutphin and Tyler, 2016). Alternatively the first annulus could be missing or difficult to discern in suckers from Clear Lake Reservoir. Validating the identification of the first annulus is needed in order to determine if a size difference exists between age- 0 suckers in the two lakes.

\section{Afflictions}

Lernaea spp. parasitism was one of the most common afflictions noted on suckers captured in either lake. Lernaea spp. are an ectoparasitic copepod that can cause severe inflammation at the attachment site and may possibly provide a pathway for bacterial infection (Berry and others, 1991). The prevalence of Lernaea spp. that we observed in 2015 was similar to that reported for Upper Klamath Lake in previous years (5-21 percent; Burdick and others, 2008; Burdick and Brown, 2010; Bottcher and Burdick, 2010; Burdick and VanderKooi, 2010; Burdick and Hewitt, 2012). The prevalence of this ectoparasite was much lower in Clear Lake Reservoir in 2015 (33 percent) compared to 2014 when it occurred on 81 percent of juvenile suckers (Burdick, Elliott, and others, 2015).

The higher prevalence of petechial hemorrhages of the skin in Upper Klamath Lake compared to Clear Lake Reservoir is noteworthy. Previous studies also indicate that this affliction is associated with Upper Klamath Lake rather than Clear Lake Reservoir (Burdick, Elliott, and others, 2015). Petechial hemorrhages of the skin were not identified on suckers from Clear Lake Reservoir in 2014 (Burdick, Elliott, and others, 2015). The prevalence of this affliction was greater in 2015 than the 16 percent of affected suckers reported for Upper Klamath Lake in 2014 (Burdick, Elliott, and others, 2015). The very low prevalence of observed hemorrhages in Clear Lake Reservoir indicates that our method of capture as an abrasive factor contributing to the hemorrhages is unlikely to be the primary cause. These small hemorrhages can have various causes, including infection from various agents, toxins exposure, or abrasion (Ferguson and others, 2011).

While deformed opercula appears on a small portion of juvenile and adult suckers collected from Upper Klamath Lake annually, it has yet to be identified on suckers from Clear Lake Reservoir (Burdick, Elliott, and others, 2015). The prevalence of opercular deformities observed in 2015 suckers (5 percent) was similar to what was reported in a comprehensive juvenile sucker health evaluation in both lakes conducted in 2013 and 2014, in which 8 percent of suckers from Upper Klamath Lake and no suckers from Clear Lake Reservoir had the deformity (Burdick, Elliott, and others, 2015). 
Deformed or shortened opercula are considered non-lethal for hatchery-reared fish (Beraldo and others, 2003). Barkstedt and others (2015) found that that the prevalence of opercular deformities on three species of wild-caught catostomids decreased with age. Based on a presumption that deformed opercula are a permanent condition for catostomids, they hypothesized opercula deformities were associated with mortality. Opercular deformities may lower resistance to oxygen stress and predispose fish to infections by bacteria, parasites, and fungi (Galeotti and others, 2000; Beraldo and others, 2003), or reduce predator avoidance. These deformities have numerous potential causes including low $\mathrm{pH}$, inbreeding, hybridization (Winemiller and Taylor, 1982; Tringali and others, 2001), nutritional deficiency (Chávez de Martínez, 1990; Lall, 2002), heavy metals, pesticides, high egg incubation temperatures (Boglione and others, 2013) and parasites (Quist and others, 2007). Nutrition related to skeletal deformities in fish includes too much or too little dietary bioavailable phosphorus $(\mathrm{P})$ relative to calcium uptake and deficiencies in vitamins $\mathrm{C}$ and $\mathrm{D}$, phospholipids, unsaturated fatty acids, or magnesium (Lall, 2002; Cahu and others, 2003). Deformed opercula also have been noted at low rates in hatchery-reared Lost River suckers, which may indicate that the causes are genetic, temperature related, or nutritional (U.S. Geological Survey, unpub. data, 2014).

The black spots observed on suckers from Upper Klamath Lake were presumed to be melaninencysted metacercaria of trematodes, based on previous histology on suckers with similar spots (Burdick, Elliott, and others, 2015). Black spot forming parasites were not identified on suckers from Clear Lake Reservoir in either 2014 or 2015 (Burdick, Elliott, and others, 2015). It has previously been hypothesized that this parasite is associated with mortality of suckers in Upper Klamath Lake (Markle and others, 2014). Metacercaria of trematodes can infect multiple tissues. Therefore, non-lethal field examination, such as we conducted likely underestimates the true prevalence and intensity of infection of this parasite.

Different age compositions of juvenile suckers in Upper Klamath Lake and Clear Lake Reservoir provide information about population dynamics in these two systems. The lack of suckers captured from Clear Lake with no annuli is consistent with data collected in 2014 when all suckers collected had one or more annuli (Burdick, Elliott, and others, 2015). When catch data collected over several years are considered, production of age-0 juvenile suckers appears to be variable if not intermittent in Clear Lake Reservoir (Burdick and Rasmussen, 2012, 2013; Burdick, Elliott, and others, 2015). This dynamic is not as concerning for Clear Lake Reservoir suckers as it might be if not for the relatively (compared with Upper Klamath Lake) high apparent survival of juvenile suckers in that system. In contrast, production of age-0 suckers in Upper Klamath Lake is potentially variable in its magnitude but occurs at some level annually (Hendrixson, Burdick, Herring, and others, 2007; Hendrixson, Burdick, VanderKooi, and others, 2007; Burdick and others, 2008; Burdick and Hewitt, 2012). Production of young-of-the-year suckers in Upper Klamath Lake, however, appears to be negated by high mortality. While the cause of the apparent difference in production of young suckers between lakes appears to be associated with flow in spawning tributaries, the causes of differential mortality between lakes is unknown. Differences in the prevalence of afflictions between lakes may offer clues, but more research is required to determine why juvenile sucker apparent mortality is relatively high in Upper Klamath Lake. 


\section{References Cited}

Allen, M.S., and Hightower, J.E., 2010, Fish population dynamics-Mortality, growth, and recruitment, in Hubert, W.A., and Quist, M.C., eds., Inland fisheries management in North America ( $3^{\text {rd }}$ ed.): Bethesda, Maryland, American Fisheries Society, p. 43-80.

Barkstedt, J.M., Farrington, M.A., and Kennedy, J.L., 2015, Frequency of opercular deformities in age0 native catostomids in the San Juan River from 1998 to 2012: Albuquerque, New Mexico, American Southwest Ichthyological Researchers, L.L.C., 38 p.

Beraldo, P., Pinosa, M., Tibaldi, E., and Canavese, B., 2003, Abnormalities of the operculum in gilthead sea bream (Sparus aurata)—Morphological description: Aquaculture, v. 220, p. 89-99.

Berry, C.R., Jr., Babey, G.J., and Shrader, Terry, 1991, Effect of Lernaea cyprinacea (Crustacea: Copepoda) on stocked rainbow trout (Oncorhynchus mykiss): Journal of Wildlife Diseases, v. 27, p. 206-213.

Boglione, C., Gisbert, E., Gavaia, P., Witten, P.E., Moren, M., Fontagne, S., and Koumoundours, G., 2013, Skeletal anomalies in reared European fish larvae and juveniles - Part 2-Main typologies, occurrences and causative factors: Reviews in Aquaculture, v. 5, no. 1, p. S121-S167.

Bottcher, J.L., and Burdick, S.M., 2010, Temporal and spatial distribution of endangered juvenile Lost River and Shortnose Suckers in relation to environmental variables in Upper Klamath Lake, Oregon-2009 annual data summary: U.S. Geological Survey Open-File Report 2010-1261, 42 p.

Burdick, S.M., Anderson, G.O., and VanderKooi, S.P., 2009, Spring and summer spatial distribution of endangered juvenile Lost River and shortnose suckers in relation to environmental variables in Upper Klamath Lake, Oregon-2007 Annual Report: U.S. Geological Survey Open-File Report 2009-1043, $56 \mathrm{p}$.

Burdick, S.M., and Brown, D.T., 2010, Distribution and condition of larval and juvenile Lost River and shortnose suckers in the Williamson River Delta restoration project and Upper Klamath Lake, Oregon-2009 annual data summary: U.S. Geological Survey Open-File Report 2010-1216, 78 p.

Burdick, S.M., Elliott, D.G., Ostberg, C.O., Conway, C.M., Dolan-Caret, A., Hoy, M.S., Feltz, K.P., and Echols, K.R., 2015, Health and condition of endangered juvenile Lost River and shortnose suckers relative to water quality and fish assemblages in Upper Klamath Lake, Oregon, and Clear Lake Reservoir, California: U.S. Geological Survey Open-File Report 2015-1217, 56 p., http://dx.doi.org/10.3133/ofr20151217.

Burdick, S.M., and Hewitt, D.A., 2012, Distribution and condition of young-of-year Lost River and shortnose suckers in the Williamson River Delta restoration project and Upper Klamath Lake, Oregon, 2008-10_Final Report: U.S. Geological Survey Open-File Report 2012-1098, 52 p.

Burdick, S.M., Hewitt, D.A., Rasmussen, J.E., Hayes, B.S., Janney, E.C., and Harris, A.C., 2015, Effects of lake surface elevation on shoreline-spawning Lost River Suckers: North American Journal of Fisheries Management, v. 35, p. 478-490.

Burdick, S.M., and Rasmussen, J., 2012, Preliminary juvenile Lost River and Shortnose Sucker investigations in Clear Lake, California—2011 pilot study summary: U.S. Geological Survey OpenFile Report 2012-1180, 18 p.

Burdick, S.M., and Rasmussen, J., 2013, Age and condition of juvenile catostomids in Clear Lake Reservoir, California: U.S. Geological Survey Open-File Report 2013-1188, 20 p.

Burdick, S.M, and Vanderkooi, S.P., 2010, Temporal and spatial distribution of endangered juvenile Lost River and shortnose suckers in relation to environmental variables in Upper Klamath Lake, Oregon—2008 annual data summary: U.S. Geological Survey Open-File Report 2010-1051, 36 p. 
Burdick, S.M., Wilkens, A.X., and VanderKooi, S.P., 2008, Near-shore and off-shore habitat use by endangered juvenile Lost River and shortnose suckers in Upper Klamath Lake, Oregon-2006 data summary: U.S. Geological Survey Open-File Report 2007-1356, 30 p.

Cahu, C., Infante, J.Z., and Takeuchi, T., 2003, Nutritional components affecting skeletal development in fish larvae: Aquaculture, v. 227, p. 245-258.

Chávez de Martinez, M.C., 1990, Vitamin C requirements of the Mexican native cichlid Cichlasoma urophthalmus (Gunther): Aquaculture, v. 86, p. 409-416.

Clavero, M., Blanco-Garrido, F., and Prenda, J., 2006, Monitoring small fish populations in streams-A comparison of four passive methods: Fisheries Research, v. 78, p. 243-251.

Cooperman, M., and Markle, D.F., 2003, Rapid out-migration of Lost River and shortnose sucker larvae from In-River spawning beds to in-lake rearing grounds: Transactions of the American Fisheries Society, v. 132, p. 1,138-1,153.

Ellsworth, C.M., and Martin, B.A., 2012, Patterns of larval sucker emigration from the Sprague and lower Williamson Rivers of the Upper Klamath Basin, Oregon, after the removal of Chiloquin Dam2009-10 annual report: U.S. Geological Survey Open-File Report 2012-1037, 34 p.

Evanno, G., Regnaut, S., and Goudet, J., 2005, Detecting the number of clusters of individuals using the software STRUCTURE - A simulation study: Molecular Ecology, v. 14, p. 2611-2620.

Ferguson, J.A., Koketsu, W., Ninomiya, I., Rossignol, P.A., Jacobson, K.C., and Kent, M.L., 2011, Mortality of coho salmon (Oncorhynchus kisutch) associated with burdens of multiple parasite species: International Journal for Parasitology, v. 41, no. 9, p. 1197-1205.

Galeotti, M., Beraldo, P., de Dominis, D., D’Angelo, L., Ballestrazzi, R., Musetti, R., Pizzolito, S., and Pinosa, M., 2000, A preliminary histological and ultrastructural study of opercular anomalies in gilthead sea bream larvae (Sparus aurata): Fish Physiology and Biochemistry, v. 22, p. 151-157. Hamley, J.M., and Regier, H.A., 1973, Direct estimates of gillnet selectivity to walleye (Stizostedion vitreum vitreum): Journal of the Fisheries Research Board of Canada, v. 30, p. 817-830.

Hendrixson, H.A., Burdick, S.M., Herring, B.L., and VanderKooi, S.P., 2007, Near-shore and off-shore habitat use by endangered, juvenile Lost River and shortnose suckers in Upper Klamath Lake, Oregon-Annual report 2005: Report of U.S. Geological Survey, Western Fisheries Research Center, Klamath Falls Field Station to the Bureau of Reclamation, Mid-Pacific Region, Klamath Falls, Oregon, 109 p..

Hendrixson, H.A., Burdick, S.M. VanderKooi, S.P., and Wilkens, A.X., 2007, Near-shore and off-shore habitat use by endangered, juvenile Lost River and shortnose suckers, and near-shore water quality, in Upper Klamath Lake, Oregon-Annual report 2004: Report of U.S. Geological Survey, Western Fisheries Research Center, Klamath Falls Field Station to the Bureau of Reclamation, Mid-Pacific Region, Klamath Falls, Oregon.

Hewitt, D.A., and Hayes, B.S., 2013, Monitoring of adult Lost River and shortnose suckers in Clear Lake Reservoir, California, 2008-2010: U.S. Geological Survey Open-File Report 2013-1301, 18 p., http://dx.doi.org/10.3133/ofr20131301.

Hewitt, D.A., Janney, E.C., Hayes, B.S., and Harris, A.C., 2015, Status and trends of adult Lost River (Deltistes luxatus) and shortnose (Chasmistes brevirostris) sucker populations in Upper Klamath Lake, Oregon, 2014: U.S. Geological Survey Open-File Report 2015-1189, 36 p., http://dx.doi.org/10.3133/ofr20151189.

Hoy, M.S., and Ostberg, C.O., 2015, Development of 20 TaqMan assays differentiating the endangered shortnose and Lost River suckers: Conservation Genetics Resources, v. 7, no. 3, p. 673-676, doi: 10.1007/s12686-015-0474-y. 
Hubert, W., Pope, K.L., and Dettmers, J.M., 2012, Passive captured techniques, in Zale, A.V., Parrish, D.L., Sutton, T.M., and Sutton, T.M., Fisheries Techniques ( $3 \mathrm{~d}$ ed): Bethesda, Maryland, American Fisheries Society Press, p. 223-266.

Kraft, C.E., and Johnson, B.L., 1992, Fyke-net and gill-net size selectivity for yellow perch in Green Bay, Lake Michigan: North American Journal of Fisheries Management, v. 12, p. 230-236.

Laarman, P.W., and Ryckman, J.R. 1982, Relative size selectivity of trap nets for eight species of fish: North American Journal of Fisheries Management, v. 2, no. 1, p. 33-37.

Lall, S.P., 2002, The minerals, in Halver, J.E., and Hardy, R.W., Fish Nutrition (3rd ed.): San Francisco, Academic Press, p. 259-308.

National Research Council, 2004, Endangered and threatened fishes in the Klamath River BasinCauses of decline and strategies for recovery: Washington, D.C., The National Academies Press, 398 p.

Markle, D.F., Cavalluzzi, M.R., and Simon, D.C., 2005, Morphology and taxonomy of Klamath basin suckers (Catostomidae): Western North American Naturalist, v. 65, no. 4), p. 473-489

Markle, D.F., Terwilliger, M.R., and Simon, D.C., 2014, Estimates of daily mortality from Neascus trematode in age-0 Shortnose Sucker (Chasmistes brevirostris) and the potential impact of avian predation: Environmental Biology of Fish, v. 97, p. 197-207.

Pritchard, J.K., Stephens, M., and Donnelly, P., 2000, Inference of population structure using multilocus genotype data: Genetics, v. 155, p. 945-959.

Quist, M.C., Bower, M.R., and Hubert, W.A., 2007, Infection by a black spot-causing species of Uvulifer and associated opercular alterations in fishes from a high-desert stream in Wyoming: Diseases of Aquatic Organisms, v. 78, p. 129-136.

$\mathrm{R}$ Core Team, 2013, R-A language and environment for statistical computing: Vienna, Austria, $\mathrm{R}$ Foundation for Statistical Computing, ISBN 3-900051-07-0, http://www.R-project.

Simon, D., Terwilliger, M.R., and Markle, D.F., 2013, Annual report for project, larval and juvenile ecology of Upper Klamath Lake suckers-2012: Oregon State University Report to Bureau of Reclamation, $88 \mathrm{p}$.

Sutphin, Z., and Tyler, T., 2016, Entrainment of early life-stage of fish from Clear Lake Reservoir into Lost River: Bureau of Reclamation internal report, $25 \mathrm{p}$.

Tringali, M.D., Ziemann, D.A., and Stuck, K.C., 2001, Preliminary aspects of genetic management for Pacific Threadfin Polydactylus sexfilis stock enhancement research in Hawaii, in Nakamura, Y., McVey, J.P., Leber, K., Neidig, C., Fox, S., and Churchill, K., eds., Ecology of aquaculture species and enhancement of stocks, Proceedings of the U.S.-Japan Meeting on Aquaculture, 30th, December 3-4, 2001, Sarasota, Florida: Cooperative Program in Natural Resources (UJNR) Technical Report, no. 30, p. 55-74.

U.S. Fish and Wildlife Service, 1988, Endangered and threatened wildlife and plants-Determination of the Status for the Shortnose Sucker and Lost River Sucker: Federal Register, v. 53, no. 137, p. 2713027134.

U.S. Fish and Wildlife Service, 2013, Revised recovery plan for the Lost River Sucker (Deltistes luxatus) and Shortnose Sucker (Chasmistes brevirostris): U.S. Fish and Wildlife Service, Pacific Southwest Region, Sacramento, California. xviii +122 p.

Winemiller, K.O., and Taylor, D.H., 1982, Inbreeding depression in the convict cichlid Cichlosoma nigrofasciatum (Baird and Girard): Journal of Fish Biology, v. 21, p. 399-402. 
Publishing support provided by the U.S. Geological Survey

Science Publishing Network, Tacoma Publishing Service Center

For more information concerning the research in this report, contact the Director, Western Fisheries Research Center U.S. Geological Survey

6505 NE 65th Street

Seattle, Washington 98115

http://wfrc.usgs.gov/ 
